\title{
THREAD: \\ Managing context in project environments
}

BY

FLORA LU

A thesis submitted to the Victoria University of Wellington in fulfilment of the requirements for the degree of Master of Innovation and Commercialisation

Victoria University of Wellington

2018 

“...the thread of knowledge, once you pull at it, continues unraveling on its own."

- $\quad$ Lauren Binet 



\begin{abstract}
Creative design agencies are unique organisations as various disciplines and priorities combine to deliver solutions in often complex client problems. A suite of software platforms is used in the day-to-day operations of project-based organisations, however there still appears to be a disconnect between communication and shared understanding. While the market for project management software is saturated, a need exists for a complementary platform that can help encourage shared understanding throughout the client project lifecycle.
\end{abstract}

This project aims to explore issues of boundary spanning, project knowledge management, and communication with DNA Design serving as a project partner. In this exploratory research process, a qualitative research approach revealed several issues revolving around inadequate handover processes, low work self-efficacy, and a lack of alignment between priorities.

The core finding of this project found that while practitioners do communicate throughout the project lifecycle, there is no one best fit for all project members and despite the high levels of communication, many practitioners feel they lack the necessary information and understanding in a client project. From this core finding, the product development strategy pivoted. Instead of developing and implementing a knowledge repository, it could be more beneficial for DNA and other project-based organisations to consider strategies and technologies to actively manage expectations and understanding within a client project.

The proposed solution, Thread, aims to track each project team members' attitudes at a regular interval to map the stage of the project lifecycle and provide DNA a bird's-eye view of the user experience of project team members to allow for active project management during the project lifecycle and a quantifiable post-project review process.

It is hoped the recommendations and proposed solution can be scaled to other projectenvironment organisations as the challenges of knowledge sharing and communication are felt heavily in multi-disciplinary teams and organisations. As the future of organisations are moving towards specialised knowledge workers, it is increasingly important that staff are aware of the context of the project to be empowered and productive. 



\section{Acknowledgements}

“When it falls down, who you gon' call now?"

- Kanye West

First of all, my sincerest thanks to Gren, Chris and Rachel at DNA, and everyone who has talked to me. THANK YOU for this amazing learning experience, your time, and hopefully this will be of some value to you.

To the MInnComl team. Thank you Jenny for all the support this year. Adrian, Darsh, Jacob, Mitchell - Thanks for all the banter.

Jocelyn, I could not have asked for a better supervisor. Thank you for all the help, the feedback, the vitamins, the camping gear, but most of all, the opportunities and experience. Thank you so much for all the chats and life advice. I've never been more inspired to continue learning than this year, I've learnt that there is still a lot that I don't know, there is still a lot for me to learn.

Cheers to all my friends who listened to me complain about this thesis. Thanks to all my emergency contacts in situations that aren't really emergencies. Thanks for all the jugs, the banter, the laughs. Especially to all the East girls who have been for the ride that were these past years. It feels like they have been the most challenging, disastrous, and rewarding years and I'm glad and grateful that we were on all the same journey. Although I know that life will take us to different places, I'm just really glad we crossed paths at some point or another. If you think this is for you, it probably is.

Lastly, thanks to my family for all their love and support. Twenty-two years, twenty-two years of this mess. Thanks for always picking me up when I'm down, for supporting me. Thanks for never letting me forget where I come from, for being honest with me. For teaching me when to take advice and when you have to make the mistakes to learn the lesson. Thanks for all the sacrifices made so I can have the best. I'm still working on some things but I'm getting there.

I'm sure there are so many people that I haven't mentioned but I truly am standing on the shoulders of giants.

I'm out.

"From the land of flightless birds, bout to grow really big wings." 



\section{Table of Contents}

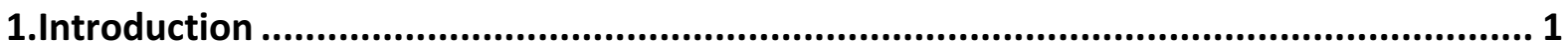

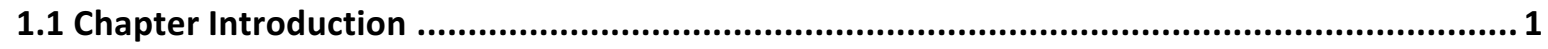

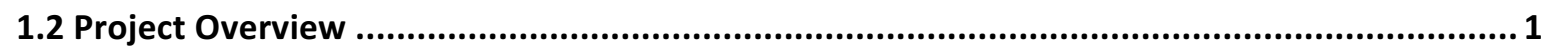

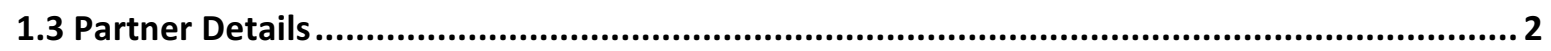

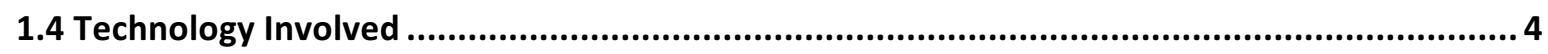

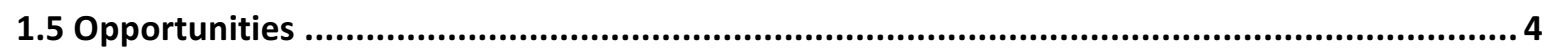

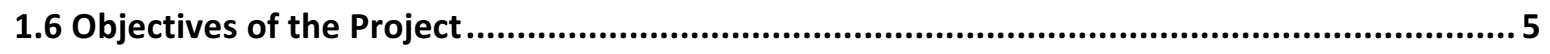

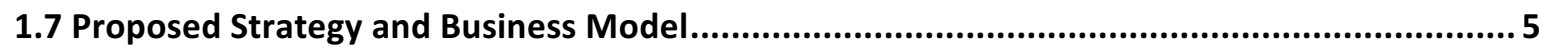

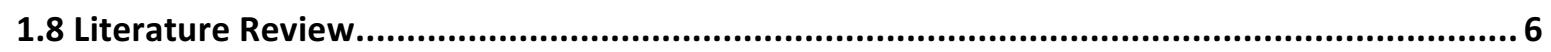

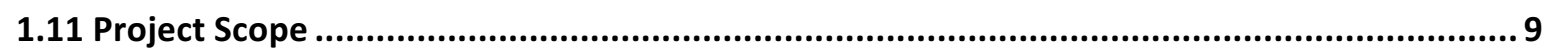

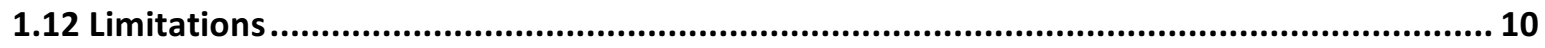

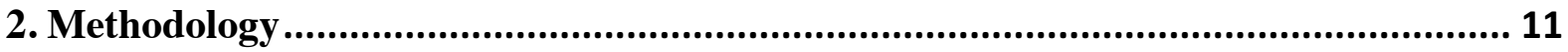

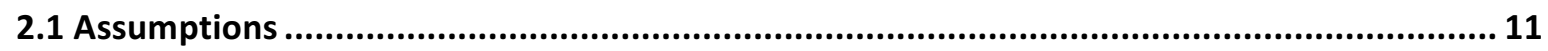

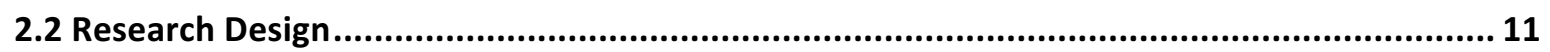

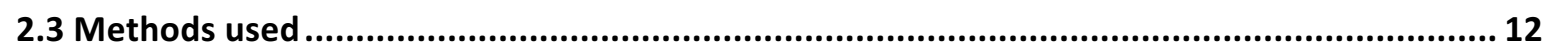

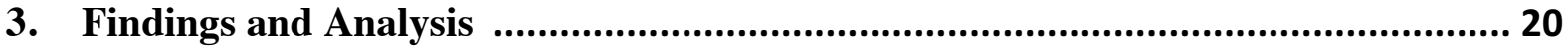

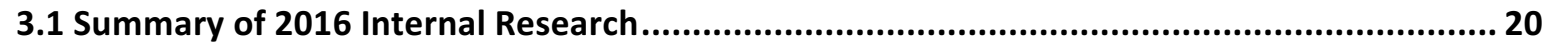

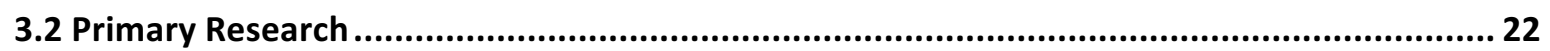

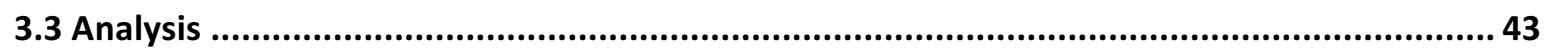

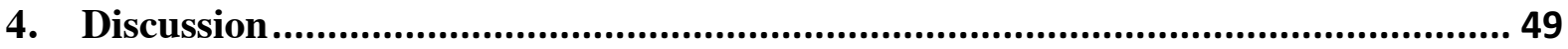

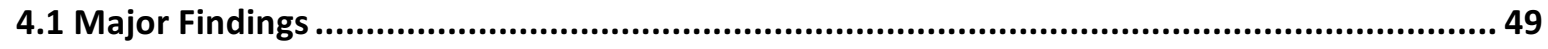

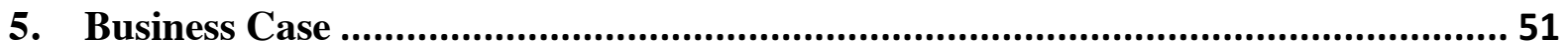

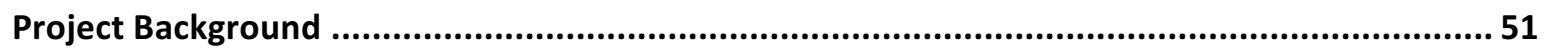

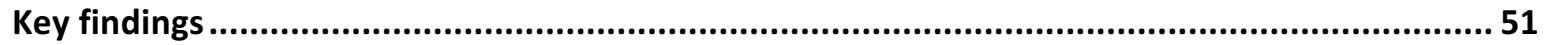

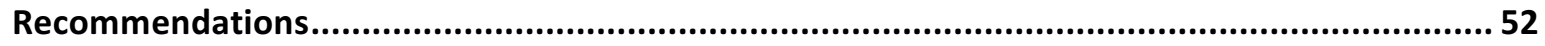

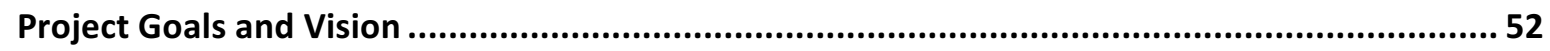

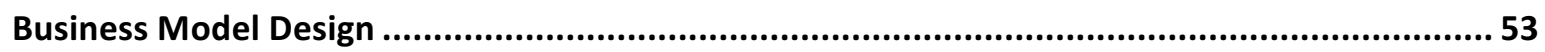

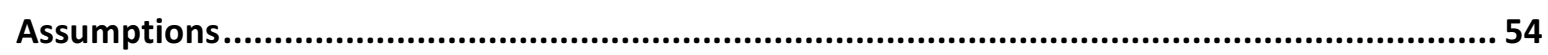

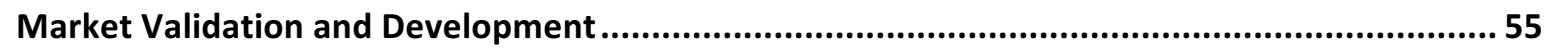

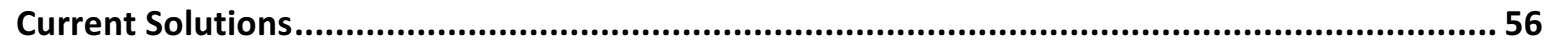

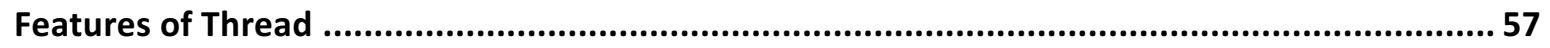

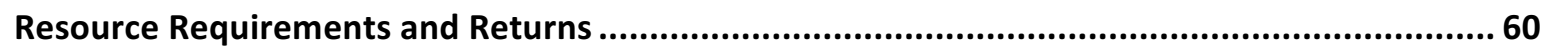

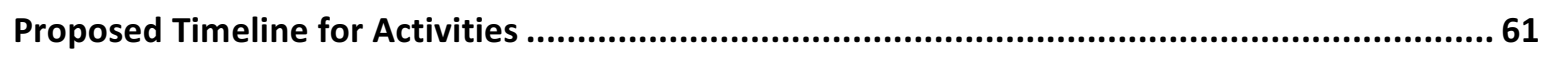

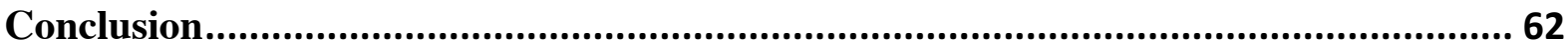

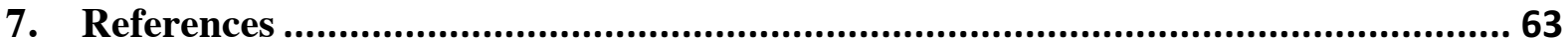

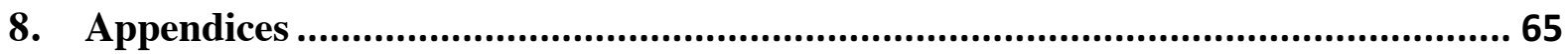




\section{Introduction}

\subsection{Chapter Introduction}

This chapter gives insight into the common problem experienced by design agencies, introduction to the project partner, outlines the opportunities presented and discuss the objectives of the report.

\subsection{Project Overview}

\section{Problem context:}

The communication 'gap' between the functional teams of designers and developers is an emerging industry problem due to a misunderstanding of what designers envision and what is feasible from a development standpoint (Hager, 2016). A misalignment of priorities can create feedback loops between functional teams, hinder utilisation rates (productivity) and creates customer dissatisfaction which reduces prospective clients' desire to work with the organisation.

In a design agency, understanding the project scope and client needs and wants are crucial to a successful project. Design inherently is a collaborative creative process where artefacts are visual and knowledge transferred through visual and verbal (tacit) means. Creative teams often work in project environments that are complex and ever-changing. This causes a double-pronged problem firstly, for the organisation, and secondly, for team members. In the initial client meeting, often seen as the most crucial point of contact as most staff members want to be in the room to get the richness of the information.

Soft project knowledge shifts and is filtered down from individual to individual, leading to a game of 'Chinese whispers' that can cause inefficiency leading to low project profit margins, and low efficacy and job satisfaction for some project members. Misalignment of project understanding causes budget blowouts, which has negative effects on team dynamic and firm reputation, affecting both internal and external stakeholders.

\section{Research problem:}

Although DNA Design prides itself on being an award-winning, solutions-focused user experience agency, the internal user experience of staff members has room for improvement. 
This project aims to explore how knowledge sharing strategies and processes at and individual-, project-, and organisational-level to improve processes at DNA to improve job satisfaction, increase profit, and encourage organisational learning.

In doing so, the project aims to understand how multi-disciplinary (and often siloed) organisations can use knowledge management strategies to improve efficacy and efficiency? Furthermore, why is there a suite of technological platforms to use, why not one that bridges the knowledge between individuals, projects, and the organisation?

In order to develop a new strategy, process or platform that better fits DNA, there is a need to understand what is defined as "context" in a multi-disciplinary project environment, and what knowledge management strategies can be improved or developed be used to improve efficacy and efficiency.

\subsection{Partner Details}

DNA Design is a customer experience agency with offices in Wellington and Auckland. With a team of around fifty, practitioners work on commercial clients across the public and private sector (DNA Designed Communications Limited, 2018). Client projects involve multidisciplinary teams with some projects spanning across research, UX, design, development and project managers.

DNA Design provides a unique environment to explore the factors of organisational culture and structure, nature of work, and technologies in relation to knowledge sharing as DNA is a knowledge intensive organisation. Furthermore, staff are siloed within functional teams, despite the small relative size of the organisation, with thirty in the Wellington office and twenty in the Auckland office.

The communication 'gap' between the functional teams of designers and developers is an emerging industry problem due to a misunderstanding of what designers envision and what is feasible from a development standpoint (Hager, 2016). A misalignment of priorities can create feedback loops between functional teams, hinder utilisation rates (productivity) and create customer dissatisfaction which reduces prospective clients' desire to work with DNA. 
As an 'experience' design consultancy, the nature of work at DNA is project-based. Although the Wellington team perceives their project methodology to be an iterative process, handovers can remain largely linear. The breakdown in the end-to-end process perpetuates low efficacy among staff members further down the project workflow and encourages silo mentality.

Technology permeates the day-to-day operation and project processes of DNA. This includes platforms for project management, to share work-in-progress internally, and synchronous and asynchronous communication.

However, functional teams often have preferred platforms that suit their roles. Jira and Confluence are used by developers and project managers, often to flag bugs and communicate updates. Designers favour InVision to share prototypes with teams and clients. Project managers tend to use a selection of PM platforms, including Trello, Float and Asana which could ineffective due to low rates of adoption. Research will aim to better understand the causes for this technological diaspora.

Other considerations are organisational culture as DNA emphasises design thinking which involves physicality, dialogue, and iteration. This creates a conflict between the codification of knowledge and how knowledge is created and transferred at DNA. Visualisation and workshopping are essential processes, however valuable insight in discussions and tacit knowledge largely remain with staff members rather than being transformed into organisational learning (Chris Jackson, personal communication, March 6, 2017).

Furthermore, DNA is a business. Therefore, the goal to achieve higher efficiencies in order to increase productivity, and therefore, profit, underlies the research. By increasing communication and satisfaction on projects, job satisfaction and retention increases, also giving the advantage of retaining knowledge or allowing more opportunities for transfer of knowledge.

Concerns for DNA include balancing between resourcing (staffing the right practitioners on the right projects) and communicating information within projects and across the organisation. Learning, in individuals and in the organisation, is fundamental to DNA's 
success in the future. The project will examine the trade-off between codification and personalisation knowledge management strategies and which one will best fit DNA to leverage their current capabilities and develop future capabilities.

\subsection{Technology Involved}

The proposed product, Thread, will fill a niche gap in the project management software market for a platform that works alongside current project management software and workflow tools. Thread fills the niche where current platforms fail. The current competitive landscape of project management and workflow management software focuses on task management. Often things are not captured live, or in retrospect, and carry bias from interactions and experiences. Thread came to be a process-focused workflow and developmental knowledge management application (Binney, 2001) through multiple iterations.

Thread is a project-centric cross-platform software that evaluates the state of knowledge across functional groups. It became appear in the research project that it is critical a tool is needed to evaluate the alignment of project knowledge in context-rich projects in order to encourage the creation of shared understanding and reduce project creep.

\subsection{Opportunities}

The issues of sharing project context and communication are not unique to DNA. While the main stakeholder is DNA Design, and the organisation benefits from an assessment of internal capabilities and recommendations for knowledge sharing platforms and processes. However, communication breakdown and knowledge sharing issues are not unique to the organisation. Current literature on knowledge management focuses on IT projects and organisations where knowledge codification is best practice (ie. health, government, education). A different scope of research into potential commercialisation opportunities for a knowledge sharing platform in a creative industry is possible by first understanding DNA's needs.

Two main segments can stand to benefit from the research and findings - creative firms and 
project-based organisations. Firms in the creative industry often are uncomfortable with the notion of knowledge codification as it perceived as rigid and opposes the fluidity of design thinking. Project knowledge in creative firms is often information-rich and difficult to codify.

Additionally, functional teams tend to form silos unconsciously in project-based organisations. This project aims to understand notions about knowledge sharing and functional teams to create a solution which can benefit creative project teams in various sectors. The fluid nature of project-based organisations can be a double-edged sword. On one hand, it allows for flexibility and the best members to be put onto the team, however, there could be a lack of shared understanding as team members weave in-and-out of projects.

\subsection{Objectives of the Project}

The fundamental project objective is to better understand knowledge management in a siloed organisation with multi-disciplinary teams. Underlying that are the objectives to understand how DNA learns as an organisation, how best to transfer knowledge to members on projects, and what are the implications and opportunities of these findings for DNA.

Subsequent project objectives can be summarised as follows:

- To understand the values of DNA staff members in their roles;

- To understand the project life cycle at DNA and common pain points throughout the project life cycle;

- To understand what knowledge management features are needed to optimise project workflows at DNA;

- To design and develop knowledge management processes and platforms for DNA according to DNA's needs;

- To explore commercialisation opportunities for DNA's knowledge management processes and platforms.

\subsection{Proposed Strategy and Business Model}

\section{Opportunities for Commercialisation}

It is expected DNA will have a say in what commercialisation options are viable as they have a stake in developing the platform. Although no payment is expected from DNA to Victoria University or the researcher for the research project and insights created, it is likely a IP 
licensing or SaaS business model will be explored to understand the commercialisation process. Further investigation into commercialisation opportunities will take place once a clearer product and value proposition is developed.

With scalability and a wider market in mind, DNA can serve as the pilot for a proposed platform or business case for why such a platform needs to be developed. In understanding how DNA learns, it is hoped a valuable knowledge management platform can bridge gaps between functional teams, increase meaningful communication, efficacy and productivity across a range of sectors.

\subsection{Literature Review}

At its core, this project aims to investigate knowledge management in project organisations. Therefore, the area of project knowledge management must be explored first before understanding the intricacies of boundary spanning and alignment of professional values. As the project was exploratory, the initial literature review consisted of literature around knowledge management and project knowledge management.

Current academic literature focuses on knowledge management in engineering and information technology fields. A similar study to understand shared meaning across engineers, assemblers, and technicians found that the different functional teams worked in different contexts and created common ground through "universal" language to decontextualise and create shared understanding (Bechky, 2003). Bechky's case guides this project in the transformation of local understandings.

Although the project will not explore organisational culture thoroughly, it is acknowledged that organisational culture hugely influences communication and the culture of knowledge sharing in an organisation. This project adopts the multi-culture view of organisational culture (Turner, 1994) as three distinct groups of disciplines are investigated - project managers, designers, and developers.

Hanisch, Lindner, Mueller, \& Wald found that employees in temporary project organisations reported an "urgent need" for improvement in project organisations (2009). Furthermore, project management strategies were implemented in hopes of avoiding duplication of work, 
achieve learning by repetition, promote innovation, standardise best practice, and achieve the efficient allocation of resources (p. 152, 2009), however, the reality is that only a few organisations are able to achieve these goals using project knowledge management during the project life cycle.

Although knowledge codification strategies can be used to retain organisational learning (Hansen, Nohria, \& Tierney, 1999), some project environments are not conducive to codification strategies and technologies due to the highly specialised nature of work (Hanisch et al., 1999). It is acknowledged that the nature of project work - time pressure and varied project commitment of project members - hinders project-based organisations' ability to codify and transfer learning (Swan, Scarbrough, \& Newell, 2010). Furthermore, formal project learning tools, such as end of project reviews and lessons learnt databases, could "tokenistic" and create inertia. Therefore, learning in projects relies on team members' experience and what is learnt in a project "goes no further than the project itself or, at best, is transferred through individuals moving on to new projects or through personal networks" (p. 340).

Similarly, Mueller investigates organisation-wide learning, the process of knowledge sharing between projects teams and how employees and project team leaders use formal and informal practices for knowledge sharing between project teams despite boundaries (2015). While organisations implement formal cross-boundary knowledge sharing strategies, some informal knowledge sharing strategies were reported to be more effective.

Knowledge sharing can be achieved without formal organisational processes with certain favourable manifestations and values (Mueller, 2012). While a matrix structure, personal responsibility, intrinsic motivation, management's trust in employees and output orientation helps knowledge sharing between project teams, although the lack of time for documentation hinders knowledge sharing (p. 442).

Reich, Gemino, \& Sauer introduced a theoretical model that demonstrated knowledge alignment can positively impact project performance and business value (2014). Reich et al (2014, p. 593) concludes "the goal of knowledge management is not to create knowledge homogeneity across project team members but to equip them to exercise their own specialist 
expertise while being alert to the consequences of their decisions on others." DNA currently lacks Knowledge Alignment, defined as "the shared understanding between the IT, Business and Governance teams and congruence between the artefacts that represent knowledge of IT, organizational and business processes, and business value" (p. 592).

At the end of the project, it was discovered that there is currently a gap in the literature for research about the assessment of project knowledge sharing within one project life cycle, presenting an opportunity for further empirical research in the field.

\subsection{Overview of the Current Market of Knowledge Management Tools}

There is no denying that the organisational communication and project management software markets are saturated. The suite of tools used at DNA is an example of this. InVision serves as the current leading competitor with features geared towards prototyping mobile and online designs (InVision, 2017), Slack dominates the messenger market with its simple-to-use file sharing feature (Salesflare, 2018), and Confluence and Jira for documentation (Caldwell, 2017).

Thread will not aim to compete with the incumbents of the industry but act as a supplementary tool that can help organisations measure the level of understanding within a project team. Exploring the competitive landscape and how best Thread can be integrated with current platforms will inform how best to meet the needs of this gap in the market.

\subsection{Key Assumptions}

The main assumption of this project is that understanding project knowledge management and sharing at DNA can address the main breakdown in communication, low efficacy, and improve productivity.

Underlying assumptions include:

- A knowledge sharing breakdown does exist within DNA and other project-based environments.

- DNA is a siloed organisation. Functional teams operate well within their boundaries and established organisational structures and processes inadvertently perpetuate those boundaries. 
- Tools and processes currently in place can encourage these confines. Different functional teams prefer different technological platforms which can hinder the transfer of knowledge and there is no consensus on one best platform across teams.

- Not all knowledge is shared equally between team members and shared knowledge is framed within the priorities and values of a role. That is, a project manager is likely to pass down knowledge that is deemed important to their role (ie. budgets and deadlines). This framing skews data and information transferred along the knowledge chain, which can create misunderstandings in communication and misaligned priorities.

- Knowledge management and communication breakdowns are not unique to DNA and there is no current best practice for the creative sector.

The main hypotheses developed from these assumptions were:

- Increasing meaningful communication will lead to a higher level of shared understanding in projects and increased project context.

- An improved understanding of projects can improve individuals' work self-efficacy and job satisfaction, therefore they are more productive and efficient as repetition and loops are reduced.

\subsection{Project Scope}

The project involved 15 participants in one organisation based in Wellington and Auckland, New Zealand. The small sample size and geographic scope allowed for more contact with the organisation which gave an initial understanding into the design organisation culture.

For this project, the scope has been limited to commercial design organisations based in Wellington, New Zealand to keep the project manageable as there were several other aspects and variables that may have influenced the project and make it unmanageable within the timeframe and feasibility of the project.

The issues of organisational culture, role ambiguity, human resource management, and employee motivation theories were considered but excluded from the project scope. Other aspects of knowledge management, such as virtual teams and team decision-making were also left out of scope to manage the complexity of the project. 
Although it is acknowledged that organisational culture and knowledge management processes are inter-related (Mueller, 2015), organisational culture will not be investigated thoroughly in this project as it is a broad area of research on its own.

\subsection{Limitations}

The project acknowledges it only investigates one organisation in isolation and issues present at DNA may not be representative of the all design agencies or project-based organisations. A wider consultation of other organisations was sacrificed in lieu of an in-depth analysis of one organisation as it is an exploratory research project that sought to uncover deeper issues of project processes rather than common surface issues that organisations may face.

\subsection{Structure of Project Report}

The project report will go on to discuss the research and product development methodology, raw findings and analysis, major findings and discussion, business case and recommendations, and plans for product development. 


\section{Methodology}

\section{Chapter introduction:}

This chapter discusses the research design and methodology that explores why there is a knowledge sharing breakdown at DNA. The research design and methodology aimed to be very exploratory and attempted to understand what the end user wants, not just in a technological platform, but in their role working in projects. That is, how can a technological platform or process help improve their role. This will be achieved through discussion with participants and understanding participants' perspective on organisational processes. From there, product development research aimed to investigate where the knowledge-intensive tasks are, what context is needed, and how best to communicate those.

\subsection{Assumptions}

Product development assumptions:

The main assumption made was there is no current best practice or software for siloed organisations. Although there are a range of technologies and platforms, there exists no platform or strategy for organisations with siloed functional teams to communicate within projects and across teams. This was mentioned in the first meeting with the project partner, as well as demonstrated in the suite of tools staff members had to use in order to communicate across the organisation. The second assumption is that organisational priorities (profit, output) might conflict with individual priorities (job satisfaction, efficacy).

Assumptions in the business model:

The business model assumes that a subscription model or a SaaS model will best suit a technological platform, if one was to be developed. However, along the new product development process, it is possible that a technological platform may not be the best fit for the project as it is highly dependent on the final proposed solution.

\subsection{Research Design}

The research design aimed to focused on the user experience. Therefore, quantitative data analysis may not provide the richest insight into attitudes, behaviours, and processes. While quantitative data would be useful in analysing a larger sample in organisations with set clear objectives and areas for validation, the exploratory nature of the project determined 
that qualitative data would be more insightful. As the project was exploratory in the beginning, qualitative research would be a better tool to assess the 'soft' elements of small organisations and build frameworks of roles within DNA.

Furthermore, quantitative research would be useful in validating and assessing relative significance of known pain-points, however the initial research design will aim to establish what perspectives, attitudes and concerns employees of DNA may have. A case study design and exploratory design are followed throughout the project as one organisation is investigated thoroughly.

\subsection{Methods used}

\section{Ethnography}

Due to the exploratory nature of the Master of Innovation and Commercialisation programme, it was determined that the first step was to see what research project would add the most value for the project partner, DNA. Therefore, an ethnographic approach will be taken to

Observation/ethnographic research to understand the organisational norms, organisational culture, and processes (tacit knowledge) at DNA's Wellington office. Entering into ethnographic research at the Wellington office of DNA in March - April 2017 provided insight into the inner workings of the organisation, and an opportunity to spot areas for improvement. Processes, people and projects were observed from an outsider's perspective, giving an ability to absorb the environment but also critically review what DNA's strengths were, and what were areas for improvement.

\section{Secondary Research}

In 2016, DNA conducted internal surveys into 'successful' and 'unsuccessful' projects, that is, those that were profitable and those that were not. The aim of this project was to uncover themes and similarities that led to financially successful projects for DNA, rather than this project of exploring how to manage context in project environments.

The internal survey was conducted through one-on-one face-to-face semi-structured interviews with practitioners across different functions including research/UX, design, 
development and project management. DNA underwent a process overview during the time the research was conducted which may result in some outdated insights as processes would have changed (eg. sprint processes may be more refined now). Another caveat is that not all roles were included in the research and projects longer than six months were excluded.

The research had several hypotheses:

Team alignment

- $\quad$ Projects that start with open briefs where DNA help shape the project are higher value,

- Fixed price projects are more profitable than others.

Client relationship

- DNA generates more margin when working with existing clients,

- A higher level of contact with client results in more financially successful projects.

Teams and roles

- Project management as a function is undervalued by DNA and therefore, the client;

- Improved project management disciplines will improve gross profit.

Internal processes

- Large jobs that touch multiple teams and are longer in duration are less profitable.

The interview guide was designed to be exploratory - with questions about circles of interaction, priorities on the project, and levels of self-efficacy. Although, approximately 30 staff members across a range of financially successful and unsuccessful projects participated, the results were left unanalysed until March 2017 using an open card sorting approach (Olsen-Landis, 2017).

The current project prompted analysis of the raw data and high-level themes were synthesised, hypotheses accepted or rejected, and then used to inform the interview guide for this project.

\section{Primary Research}

The main research of this project was qualitative research in the form of semi-structured interviews with 15 research participants - five from Project Management and Client Services, 
six from Design, and four from Development. The sample was deemed to be representative of DNA, which has a

The interview guide was developed in a way to facilitate open discussion and build on emerging themes and attitudes from the secondary internal research. Since the previous research conducted in 2016 focused on finding similarities and commonalities across financially successful and unsuccessful project success, the interview guide used for understanding individual roles, individual attitudes about the role, perceived processes, and attitudes about current processes.

One aim of the primary research is to conduct a knowledge audit of DNA to understand knowledge flows, and at what points of the process, who key players are and other areas that could be improved. The interview guide went through two main revisions and followed a very loose semi-structured questionnaire (see Appendix C). The interview guide aimed to test out the initial assumption that understanding knowledge management and knowledge sharing at DNA can address the main breakdown in communication, low efficacy, and improve productivity.

In developing an appropriate open-question, semi-structured interview guide, the aim was to understand how DNA actually learns and retains knowledge, specifically who or where knowledge is stored. It was believed that by pinpointing the individuals or roles who can build the foundations of developing a sustainable insights bank for future commercialisation opportunities.

The initial assumptions were:

- DNA can be a siloed organisation, often where functional teams operate within their confines;

- The tools, processes and structures currently in place can encourage or contribute to these confines and different functional teams prefer different tools which hinders transfer of knowledge;

- $\quad$ Not all knowledge is shared equally between team members;

- $\quad$ The communication issues can be traced to knowledge sharing breakdowns in handover processes. 
It was decided that primary research at the Auckland office would be crucial in order to understand the differences in projects, roles and values between the Auckland and Wellington offices. Due to the smaller team and the nature of work, the Auckland team are more familiar with the sprint process and the primary research aimed to understand how project workflows might differ between offices and if the same breakdowns in communication were present in both offices.

The overall goals of the initial interview guide were to understand project workflow, processes, and tools used in both the Auckland and Wellington offices, and if differences and similarities found had any effect on the understanding of project knowledge. From the results, it was hoped that the most significant cause of communication breakdown could be investigated - whether the issue lies at the core of the project or client, the project knowledge sharing process, or internal organisational culture.

Another area of interest for the primary research was to identify which role/s holds the most project knowledge and project learning, and also which held the least. It was assumed that there exists a correlation between knowledge and self-efficacy. The final area of interest was the correlation between the factors mentioned above and any correlation between efficacy.

The initial interview guide was very similar to the final interview guide, although questions around participants' goals and what they hope to achieve in their roles and careers were omitted due to time (interviews aimed to be half an hour, although many went over). In those questions, it was hoped to understand the personal values of participants and why they might choose to enter their field of expertise and if it affected the amount of involvement they felt in their jobs, and if it had any effects on how they communicated project knowledge and what methods they might prefer.

Interview participants were made aware the interviews would be recorded and data anonymised into their roles. Data was then transcribed and coded in NVivo to understand common views and attitudes about project processes.

\section{User Journey Mapping}


In this project, it is apt to attempt to apply customer experience thinking and user journey mapping (Kalbach, 2016) to understand the roles, touchpoints and experience of employees at DNA. From the semi-structured interviews, user tasks and user goals are identified to better understand how Thread can help practitioners in creative design agencies achieve both their daily tasks and project goals.

\section{Research Participants}

The research participants were selected to form a representative sample of DNA. Participants were chosen with the help from key contact persons with the project partner and selected from a range of roles and experience to understand the needs of different areas of the company.

Fifteen participants were selected from the three disciplinary teams at DNA - project managers, designers and developers. Participants had been with DNA for more than two years and were not involved in DNA's 2016 internal review in order to understand if the views held were isolated in certain projects or felt throughout the organisation.

\section{Product Development Methodology}

The project will follow the Stage-Gate process for new product development and this report will discuss the stages of discovery, scoping and building the business case (Cooper, 2017). The project is very preliminary and exploratory as a great amount of time was focused on the discovery stage in order to generate a solution that is not currently on the market.

The focus of the project shifted from "Improving knowledge management in multidisciplinary project teams" to "Managing context in project environments" after primary research was conducted. This pivot came from findings that demonstrated the frustration of DNA staff members across all functions and with varying degrees of experience reported feeling unclear about the expectations of a client project from the client, and from the internal DNA team.

A Lean Startup methodology (Reis, 2011) will be adopted to develop a minimum viable product (MVP) in order to reassess the needs of the micro-environment, DNA, and be improved upon. The development of a knowledge management platform will begin with 
design and prototyping. An iterative process is expected to develop, test and refine iterations of the final platform, with further validation (through workshops and group discussions) at each stage of the process.

Despite best efforts to develop and validate assumptions about knowledge sharing at DNA, it was expected that pivots would take place during the research process. Being prepared to pivot and having the a welcoming mind-set to new product and strategy opportunities was crucial in this project in order to gain the most learning. In case there is a failure to create a product that can be commercialised, the research into DNA's knowledge management processes will be used to make recommendations into how best knowledge sharing processes can be improved.

\section{Wider Market Validation}

With wider commercialisation implications in mind, primary qualitative research at similar creative firms or project-based organisations was considered in order to validate the project assumptions in the meso- and macro-environment. The main challenges in doing so were privacy and confidentiality concerns, resources and time. The decision to conduct primary research at parallel organisations will be made with the input of DNA Design to avoid breaching of the partner agreement and conflicts of interest. In failing to conduct primary research, secondary data was used to validate assumptions.

\section{Limitations}

The limitations of the research include the assumption that processes and attitudes at DNA represent the industry, therefore a larger target market. Due to time restrictions, resource constraints, and Master of Innovation and Commercialisation Project Guidelines, as well as non-disclosure agreements, a larger sample of organisations could not be obtained in order to better validate findings extracted from DNA.

\section{Ethical obligations}

Ethical Statement

This project has been approved by the Human Ethics Committee \#24507.

\section{Reflection on Research Methodology}


Although the qualitative research approach through semi-structured interviews allowed for a deeper understanding of individual perspectives. However, when analysing the data from the interviews, some findings were too tangential. There were broad topics discussed by participants and it was difficult to diverge then converge, consolidate and analyse the most pressing issues.

As the questionnaire guide was intended to be more general and exploratory in order to explore what the general views were, it is suggested future research questionnaires be more specific and hone in on views about boundary spanning and shared meaning. Initially, as the project was exploratory and sought to seek wider views about knowledge management, it proved to be difficult as the project grew in complexity and in the end, the proposed product vastly deviated from the initial product ideation.

The project initially assumed the breakdowns in communication could be solved by a knowledge sharing platform or knowledge repository that can encourage organisational learning. At the beginning of the project (March 2017), it was assumed that the project existed in a complicated context according to the Cynefin framework of complexity (Snowden \& Boone, 2007). By the near end of the project, it became clear that the project operated within the chaotic context as the only constant in project environments is turbulence. Therefore, developing a traditional knowledge management system or strategy would be redundant as DNA's needs were not met by incumbents already on the market.

Challenges in the proposed product development methodology arose in the stages of design and prototyping (Osterwalder et al., 2014) due to as the development of the final MVP was not finalised until April 2018. Two other stereotypes were discarded rather late into the project, which left no time for testing.

A MVP was supposed to be developed and tested with DNA staff in order to gauge the potential market's reaction to the product and the effectiveness of the proposed solution. However, the MVP presented in this thesis has not been tested yet due to time constraints and limited skills and resources. If the project continues, it is hoped that DNA would still be interested in being a pilot to test the initial project assumptions, validate the product, and validate the value proposition. 
Upon further reflection, the proposed timeframe to commercialisation from ideation of one and a half years (the length of the Master of Innovation and Commercialisation programme) is highly optimistic for a project that was more complex than expected, especially for the very exploratory nature of the issue. If the project were to be repeated, it is highly recommended that more time be allocated to understanding the user problem and discovery stage. 


\section{Findings and Analysis}

Chapter introduction:

This chapter discusses the findings of the secondary research conducted by DNA which was then used to guide primary research. Similar themes around the lack of handover processes, a lack of understanding of project context, and a misalignment of roles were discovered.

\subsection{Summary of 2016 Internal Research}

The aim of this internal review aimed to investigate common factors in financially successful and unsuccessful client projects. The research ultimately proved to be inconclusive, finding that the financial success of a project could not be accurately predicted. While the aim of this research focused on projects and indicators of financial success, below are relevant high-level themes that were used to inform the areas of research for improving the understanding of individuals on projects.

The key high level finding is that team alignment Aligning priorities (e.g. relationship), communication, clarity around roles and responsibilities, Expectations

\section{Team dynamic and collaboration}

Although team dynamic and collaboration (eg. number of catch ups, closely working within and across teams) was mixed across financially successful and unsuccessful projects, the research demonstrated a stronger correlation between high levels of collaboration and a more positive team dynamic in projects.

Participants who reported a negative team dynamic in projects reported less collaboration, insufficient amount of regular catch ups (poor communication), inadequate handover or inability to communicate (insufficient available time), and uncertainty about team involvement. Other factors include overworked practitioners experiencing burnout, a negative relationship with the client, or a complex project which was over budget. 
Team dynamic appeared to have a direct correlation with job satisfaction. On one project that was a particularly negative experience, participants reported "the Dev team is constantly overworked", "We thought we would get fired", "People dreaded being put on the job", and "We were working as individuals in a process."

Individual work self-efficacy was also directed correlated to team dynamic. A participant reported that they "came on to colour [the financially unsuccessful project] in." Although a project could be financially successful, some participants still reported not being empowered.

\section{Handovers}

The original research did not delve into the handover process at DNA. However, many participants reported experiencing inadequate handover processes across financially successful and unsuccessful client projects. Some participants reported the preferred form of handover to be face-to-face conversations, while some reported a loss of efficiency and a lack of clarity during these conversations.

"Design assumed we [Development] understood the handover because we'd had discussions."

Constraints to adequate handovers were reported to be resourcing on other projects, contractor availability (the contractor on the project had left DNA) and budget restraints. As a result, information was often lost and impacted the quality of handover to the receiving individual or team. A lack of documentation was also cited as a factor in the loss of information.

\section{"Lots got lost in the design which became apparent in the development phase."}

Furthermore, developers reported a greater need to understand the client's requirements of the design and the project overall as they were not involved in the project planning stages. A very inefficient handover process to development was reported as handovers do not typically contain documentation but rely on descriptions from designers, or developers were left with designers' art files and left with no context as to what the purpose of the build was, what the client was trying to achieve, and the decision-making process that had taken place. 
Teams and roles

A crucial finding is that project management as a function is undervalued by the internal DNA team, and therefore, the client. While the project manager had the most contact with clients and practitioners, the view of the project manager role ranged from administration to the middleman between client and practitioner. Practitioners were not clear about the tasks of project managers although project managers tend to stay throughout the client project and is the most frequently mentioned point of contact.

\section{$\underline{\text { Client relationship }}$}

There is no clear correlation between more financially successful projects and existing client relationship. That is, an existing relationship with the client does not necessarily yield higher margins on a project. Furthermore, higher levels of contact with the client does not correlate with financially successful projects. However, participants reported having a good client relationship improved their job satisfaction.

\subsection{Primary Research}

The semi-structured interviews dove deeper into the additional findings around handovers and emerging findings about teamwork and collaboration. Although the primary surveys were conducted more than one year after the internal review, many similarities were found in the attitudes around the lack of an adequate handover process, ambiguity and lack of cohesive understanding about the project manager role, and efficacy affected by team dynamics.

DNA team members have coping mechanisms and work-arounds that work for them but there is no consensus on best fit methods of communication, information needed, and ideal styles of working.

The findings are presented in the following order:

- High-level findings about projects

○ Project context

- Team dynamics and expectations

○ Handovers

○ Time 
○ Communication

○ Documentation

- Client interaction

- Analysis of roles
○ Project managers
○ Design
○ Development

\section{High-level findings about projects}

\section{Project context}

A crucial finding is the importance of having project context. The assumption that having enough context increases job satisfaction and efficacy is proven to be true across the four disciplines teams. However, what is defined as project context differs from role to role (Bechky, 2003). The importance of having context - that is understanding why the practitioner is doing what they are doing - directly impacts practitioners' job satisfaction.

"It makes it very difficult to enjoy working when you know very little about [the project], especially when it's a massive task that's generally not the most interesting. But when given a lot more context, it makes it a lot easier to make a decision on where to go going forward as opposed to coming into it blind and just sitting there poking at code until you can find the spots that are working or aren't working." - Developer 2

However, participants have varying working styles and some project team members enjoy understanding the full decision-making process behind designs and their various iterations, while some members prefer to just see the finished design and build from it. Therefore, it can be difficult for practitioners to predict how best to communicate with their colleagues or what information the next person needs.

"It's like how can we show them the benefit of a job, of a day-to-day task in knowing more about the high level insights just by looking at that feature which is my to-do list for today. Why would I want to know more about it? So there's A; being able to know more about it and try to trace it right back, but also why would I want to know more about it rather than just build it?" - Designer 4, about communicating with a developer 


\section{Team Dynamic and Expectations}

As the project team, scope and complexity increases, internal expectations and client expectations increase. It can be more difficult to manage expectations of different functional teams as there is a lack of understanding of the priorities of different roles and what they are trying to present in the deliverable, on top of the goals of the client.

"There were multiple times where [the client] came in and pretty much said, "This didn't meet our expectations', and everyone would just feel pretty stink and shift the blame onto each other. I don't know how you manage that though." - Designer 2

A key breakdown in team expectations is practitioners not understanding the feasibility or scope of a client project in the perspective of another discipline. Participants

"We get caught out a lot by, well, we have been caught out a lot by Design and UX sitting down with the client and going, "Here's a fantastically awesome thing that we want to build and you guys will love it." Then the client being shown that and going, "Yeah, we'll love this and that." And then coming to us and we're going, "You can't build that. Well, you can build it but it might take 100 extra hours on top of what you've already offered."

- Developer 2

Due to the project environment, time for regular or ad hoc meetings fluctuates as team members are committed to other projects. Practitioners are often then left alone to guess the other team members' expectations and the expectations of the client. Unsurprisingly, smaller teams allow for better communication as it is easier to manage schedules, expectations, and priorities.

“I think it's good to get a clear idea of what everyone's expectations are. I think a lot of the time, people just assume we know things. Or they're like, "Oh they're smart, they'll figure it out." But the only way to figure it out is to actually ask what's happening."

- Designer 2

Participants referred to or acknowledged the client, showing some degree that the shared priority across the board is placing meeting the expectations of the client over than the 
expectations of the team. As expected, some clients are more flexible while others are more detail-oriented, and DNA project teams are often able to adjust their working style to that of the clients'.

There exists a perceived misalignment in the expectations and priorities of different roles. Although team dynamics appear to be overall positive, this could lead to a very siloed mentality without DNA realising, and therefore, addressing.

"I don't want to sound sort of disrespectful, I get that the business operates because it can run a profit but we don't all have backgrounds in finance. We're not here because we motivated by the numbers."

\section{- Designer 6}

"I'm more about making it look clean and sharp sort of thing, whereas some of the time the account managers don't really care about that sort of thing, which drives me nuts. Even things like Word documents I've set up all these word templates for all the account managers, made it as simple as possible."

\section{- Designer 3}

\section{Handovers}

Not only does the absence of a formalised handover process creates more ambiguity for the receiver of information but also the individual who has to decide what to handover. This confusion creates inefficiency as the receiver of the information might spent valuable project time chasing after information that could have been pre-empted.

"When you hand over, how much do you hand over? So, from CX to UX/UI - is it $C X$ 's job to go all the way to UX or is it or is it UX's job to go backwards, get some of the stuff to bring into UX? Where is the middle between handover?"

- Designer 2

Although an inadequate handover process has been reported by staff in the 2016 internal review, as of October 2017, there were no improved handover process in place, although it 
was mentioned that the Auckland office was attempting to implement meetings or workshops in order to formalise a handover procedure.

\section{Time}

Due to the nature of project environments, time is a constraint and a precious commodity. Participants from each function were aware of the trade-off between allocating time to implement adequate handover processes and billable hours. Practitioners at DNA are aware of the implications of billable hours and the impact on the business. However, staff are not empowered to have control of their time and allocate reasonable amounts to handovers and meetings.

"Handover is not something that is allocated any time so it has to be absorbed into a stage of the project where the practitioner is meant to be working on something else. For example, let's say a project moves from UX to Design, have I ever seen a budget that said handover time, inter-team handover? No. Time for handover has either got to come out of one phase or another or it's not really budgeted for so it's not really allowed for, so it doesn't really occur. That's my experience."

$$
\text { - Designer } 6
$$

Participants understand the importance of allocating time and often take initiative to pre-empt project creep, although DNA does not prioritise time for meetings and handovers as an organisation.

“So we try to go, it's okay to spend a lot of time, as long as it's productive, we don't just sit around, and you know, joke about for hours and hours. We're aware that everybody's time is precious, but it is worth spending two hours deciding exactly how we're going to run the project. Everybody understands."

- Designer 4

"I treat my time like a portfolio, like an investor where I've got my time spread over these different things and I like to just track so I've actually built my own dashboard of the projects I've got, my current load and how that's going because the team rely on every individual here to be able to flag early if they're going to get overloaded." 


\section{Communication}

There is a perception of a lack of formalised regular communication. Although daily standups were observed, participants reported that regular, weekly meetings were not part of the culture at DNA and relied on the project managers or senior practitioners on the project. However, practitioners from all teams acknowledge the importance of regular face-to-face communication in projects, especially in complex client projects across multiple functional teams.

"[The conversation between Design and Development] is invaluable. When there's no conversation, you've got a siloed piece of work, a siloed piece of work, a siloed piece of work; there's so much missing. Whereas there needs to be a level of overlap on each one. So like nearing the end of the UX stage, a Designer might get involved towards there and start crossing over. Then UX and Design do their thing, then there's that process between Design and Dev and you have got bit of crossover there."

- Developer 2

Although communication has been acknowledged as being crucial, it is difficult to conduct frequent face-to-face meetings. Project meetings are not prioritised and are often moved or cancelled due to scheduling, resourcing constraints, time constraints, and project creep. Participants reported only

"People aren't here. Not that they aren't here physically. More so that they're busy, they've got a meeting somewhere else or they just can't pin anyone down at that specific time."

- Designer 3

"I think probably regular, weekly check-ins with my senior, and as far as running the project goes, regular weekly check-ins with the project team would have given me the forum 
that I could have had my worries on a piece of paper and brought them to each of those meetings ...I find that really stressful emotionally draining to have to work out when I'm going to get to speak with the people I need to. I would have much rather have it formalised, regular, turn up to it and know that's my opportunity to talk to people so I need to come prepared to bring my questions."

-Designer 6

\section{Documentation}

The knowledge artefacts at DNA are project briefs, statement of works, SLAs which are stored mainly on Confluence and the intranet. While these documents store hard knowledge about projects, the value of the information is not realised across all disciplines. Designers, by nature of their role, find more value in face-to-face and visual communication where collaboration and feedback can take place. As found in the 2016 internal review, participants who identified as developers reported higher instances of documentation, putting notes and comments directly into written code and Jira.

While face-to-face communication is crucial to the client project process, as it is a collaborative and iterative process, the downsides of this form of communication is time and that individuals can forget information or past experiences. While a straight codification strategy would not necessarily be helpful in DNA's situation.

"On that day, I could have forgotten about that website. You never know."

- Developer 1 on a project where they suggested a better feature for the client from their previous experience

The use of Slack is prevalent with developers but it is still not the preferred form of communication and documentation. Some issues participants reported were Slack being cluttered with "personal chit chat" and memes, project channels being mixed up, and the ineffectiveness of pinning important messages on channels. Designers use Slack to communicate with developers but largely prefer ad hoc face-to-face communication amongst themselves. 
"All of a sudden everyone was using [Slack] and then someone said, "Well you've got to use Slack." I had never heard of that. It wasn't really natural. It was like [the developers] were doing it and it was natural for them and then we didn't know about it. And there's still people that don't really use it. But the problem with that for me is it's kind of cool for a quick conversation, like just saying something is going ready for testing. It gets to be a bit of a conversation about nothing, which I haven't got time for. I can't be bothered with that."

\section{- Designer 3}

"That's sometimes tricky internally, especially with creative people - they're not always readers."

- Project Manager 4

There is a lack of formal post-project reviews and knowledge gained on a project are retained within individuals. Challenging projects were discussed but learnings were not captured, and therefore, lost. In a typical client project, project managers hold knowledge about client styles, requirements and expectations, which could be used in future projects but the soft project knowledge may not be effectively captured in documentation for DNA's organisational learning.

\section{Client contact}

The expectations of the client should be carefully managed. Currently, project managers have the most contact with clients and are expected to manage the expectations of the clients as well as expectations of the internal team.

Although the 2016 internal review did not find a strong correlation between having an existing relationship with clients and a financially successful project, primary research found that participants across all disciplines believe having good relationships with clients will ease some ambiguity in projects and increase their job satisfaction. Clear, early expectations and boundaries need to be set with the client in order to solve the client issue.

"Sometimes, and through no fault of anyone, it turns out that later on down the line the client just had something in their head that's never actually been brought out of their head. No one has got to that because it had not come up. It's sort of, sometimes it's something 
crazy where you would never have even thought to ask that question. I suppose trying to get that early contact to have a standard, at least the standard set of questions answered, and then from there trying to drag more detail out to figure out exactly what the issue is. That will also circumnavigate the issue where the client is coming to you with the solution they want to have implemented rather than the problem they want solved."-Developer 3

"It's that developers often don't form those [early and trusting] relationships [with the client] until SLAs, so for the initial project we are often just kept over here when the clients kept over there." - Designer 4

\section{Analysis by Roles}

Across the board, employees at DNA pride themselves on the quality of the work and are proud to be working at DNA. However, DNA appears to highly rely on the initiative of employees to achieve the high quality of work and offer little structure to the client project process that would enable knowledge sharing and learning.

The self-reported tasks, stage of project, attitudes about context, and attitudes about handovers are investigated in the four functional teams of Project Management \& Client Services, Design, and Development.

\section{Project Management \& Client Services}

At the most basic level, participants in Project Management and Client Services are responsible for managing the project budget, deadlines and delivery. Project managers overlook the whole project, from beginning to delivery. They hold the most knowledge about the client expectations, the project and the expectations of the project (the intended output).

While project managers tend to be staffed on a project from the beginning to delivery, the level of intensity and contact can vary throughout the project as they manage their portfolio. It is during the middle of the client project that project managers are less intensive as the iterative design process takes place.

\section{$\underline{\text { Priorities }}$}


The main priorities of the role are mitigating risk and managing expectations of the client and the internal project team. This is achieved by attending to "any issues, any red flags" (Project Manager 5) while ensuring scope, timing and budgets are met.

To ensure a successful project, project delivery and an understanding of timing is essential to project managers. Timesheets are used as a method to track the allocation of resources and has been discussed as a crucial artefact for future resourcing forecasting and project forecasting. Currently, timesheets are viewed as a tedious administration task by other practitioners.

"We have got targets that are set for hourly rates and, umm, so the Development and the Design Team don't actually-- They're not too bad but at the end of the day, they don't really care [about filling in accurate timesheets] because there's no repercussions for them if they go and spend extra time on it or if it goes over budget because it's kind of no skin of their back. They're going to get paid for it anyway." - Project Manager 2

"I find [being told that you need to have full timesheets] really kind of patronising. I understand why the business needs to capture them, that they help the business to understand what time is being spent on, the utilisation of staff, so they get a sense of who's really, really busy and maybe who's underutilized and what adjustments could be made there."

- Designer 6

\section{Information Received and Shared}

The main information received comes from the client rather than the internal DNA team. It is through the project manager through which information is disseminated. However, project managers deal with a feedback loop in which issues raised by the internal DNA such as changes in scope, changes in budget, extending timelines, it is the project manager's responsibility to communicate the needs and expectations of the DNA project team back to the client.

"I suppose we're creating the information ourselves really, as project managers."

-Project Manager 5 
Information shared by project managers tend to be heavily documented in change requests and letters of variation in order to ensure transparency with both the client and the internal project team. By having consistent and clear documentation, client expectations are captured and intended to create transparency for the project team and help manage expectations internally and externally.

"Any variations of scope...I'll put that into a change request document or a letter of variation to the statement of work. We're managing the documentations as project managers ourselves."

-Project Manager 5

"Documentation. Making sure there's enough of that and usually that's done for the client but often it's required for internal as well so that people have kind of a reference point they can go back to."

-Project Manager 4

\section{Information Needed/'Context'}

The main breakdown in communicating information or knowledge occurs between project managers and the client team. Pain points for project managers are often unclear client expectations, unclear client goals, and insufficient communication. In order to scope the client project accurately for the internal project team, the project manager needs to know the boundaries in terms of budget and time that the client is willing to accept.

“With [client's] vision is budgets. So understanding [the client's] financial parameters. So what their budgets are, how they're structured, if it's like OPEX or CAPEX, things like that. What they can spend this year, what they're going to spend next year, so that we can model projects based on that structure."

\section{-Project Manager 5}

\section{$\underline{\text { How Information is Currently Received and Shared }}$}

Project managers are the most flexible with their methods of communication, adapting to different team needs, project sizes, and project budgets. However, project managers need to 
balance the right mix of people and the amount of people, the frequency of communication and budget, and manage the allocation of meetings.

In order to ensure the right balance of effective and efficient information sharing, a mix of electronic (both synchronous and asynchronous) and face-to-face communication is used. While having meetings is the most information-rich method to communicate project information, it is unrealistic to expect regular meetings so it is then up to the project manager to utilise various ways to communicate with the team.

"It's making sure that everyone's on those channels [Slack] and everyone's being fed the information effectively and efficiently because you can easily build a whole project with just meetings. Team meetings everyday just eats the budget itself. So it's making sure that those connection points with the team are regular and efficiently done through the project."

-Project Manager 4

\section{Design}

On the whole, designers work typically in the middle of client projects although this could vary depending on the scope of the project, whether it be pure research or a full-scale build. Designers at DNA has different specialisations including Research, User Experience Design, User Interaction Design, Branding, Print and Product, and Graphic Design. For the sake of simplicity and anonymity, participants are generalised as Designers.

Designers are the most involved in their role and participants who identified as designers have a lot of pride in the quality of their work and the aesthetics of the output.

"Being efficient, being on budget and making it look cool...I'd rather push it that little bit and make sure that when it's got the DNA name on it it's got the DNA name on it high, especially if it has come through me."

- Designer 4

Information is often received in staggered stages and filtered through a chain of people earlier in the project life cycle. Although the information required normally does reach the designer, 
it is usually trickled down and filtered through the project manager and research team. Client expectations are not as clear as it has been passed on by project managers or senior practitioners as designers do not generally have direct client contact.

"So [a Senior UX/UI designer], she would be the one briefing me from what [Project Manager] told her. So I would be getting fed second-hand information. If I did have issue with something, then I would go directly to the project manager."

- Designer 2

In the view of designers, the most important information to pass on and to receive are the reasoning behind the design, whether it be an experience or a visual. However, the handover process is always a rush both how a designer passes on information and how they receive it.

“...There's a new piece of information to put in here, do it. It feels like you sort of getting throwing a ball and you have to deal with it. Sort of a quick five minute run down on the project. It's normally at the end of the project where the budget has started to run out so it's just get out of here. Not much, you don't get much."

- Designer 1

"I guess the idea in that is like it's in lots of little steps, so by the time it's the official handover, [the developers] have a lot of context, they know what the thought and vision is, and then it's much smoother... I would give them a little, "Hey, read about over insights, and here are a couple of diagrams of the key goals that we want to achieve and read about that before you start looking at that picture and build it."

- Designer 4

Designers reported the need to know the changes made before, options pursued, and why the alternatives were not used in the final design. In order for the output to be built effectively, designers feel they need to convey the context and pass on the reasoning behind the decisionmaking process to create the best outcome for the user and the clients' goals.

"I've been sort of at the end of the project but it's not done yet. you don't know what the conversations that happened before. You feel a little bit lost and you start doubting 
yourself because everything you do is like, "Have they tried this before or...?" It's that uncertainty because you don't know the history of that job. I don't like that."

- Designer 1

"When a client has asked for a change and everyone thought it's like a dev change, a coding change, but it's actually more - it affects the design. They call you over and they say how do you do this and you've got no idea, no story about how this has happened. It just feels messy to me I hate that sort of messy... sort of trying to make a hash job out of something."

- Designer 1

Designers reported being the most negatively affected by not having enough project context. Although all practitioners report some degree of uncertainty that impacts their role, designers reported being emotionally frustrated and their work self-efficacy being the most affected.

"I was like, "Oh no, I have no idea where to start." I felt very overwhelmed. You're sitting there just pushing stupid stuff around a page, like I don't know what I'm doing. So it impacted time, productivity, motivation as well. You're like, 'Ugh, I have no idea what I'm doing, why should I even do it? Someone's going to tell me I'm doing something wrong so why should I even try”

- Designer 2

How information is currently received/passed on:

Designers prefer to share knowledge in a tacit way, which can lead to a loss of knowledge as it is not captured. Information is passed on through conversation and carries a lot of context as to why the prototype or design looks the way it does. Designers often sit in close proximity with each to encourage natural conversation and collaboration. While this method works well within the design team, it can pose issues for capturing knowledge and project context for handover to other functional teams.

"Well basically almost just say come over check what's happening on my screen rather than emailing visuals off. You can explain what will happen next as well. everyone, just very casual, around my desk and say, "Would you do this, does this look good?", and having options. So when you have those who put together with these options you can show 
them how you explored what you're doing. You show them your path of thinking and then it's like yes that could work or what about this. Everyone feeds in a bit and I quite like working like that, sort of everyone's collaboration." - Designer 1

There has been a conscious effort to improve the handover to the Development team although both functional teams still reported a communication breakdown as it is unclear whose responsibility it is to manage expectations and how best to do it. As designers and developers communicate very differently,

"Currently I am trying to make handover to Dev really easy. I recently found that it's just... All the Devs just work so differently. And they'll be like "I just want a little bit" and another guy will just want to know everything. just trying to find a balance between how individuals like to work."

Designers are the most involved in their role in trying to manage context-rich project knowledge and passing to the Development team. Although designers are conscientious in their role in the handover process, only one designer discussed Jira as a place to store documentation, specifically for customer experience research.

"So the downside to using Slack is that I say something, maybe two Devs will see it when they're on it, and the eight other Devs won't see it because they're not on the project. And the next time they are on the project, they would've missed what I said that time. You can pin stuff [on Slack] but if I pin 50 things that I say, it's just going to be a nightmare, everyone is going to be on different pages."

"Being involved right at the start until the end is the best way that the context is going to be carried... and then obviously there's how do we document it so that it does get [passed on]. There's carrying it for ourselves and then there is also carrying it for other people who gets involved, whether it's the client or whether it's external." 


\section{Developers}

Developers are often involved in the end of the client project, although that is changing with efforts to involve developers during the 'discovery' phase of the project and efforts to involve developers alongside designers throughout the project lifecycle. There is a conscious effort to involve developers earlier in projects, although some developers still report only being involved in the build stage, with the project being passed on from design.

"That's the thing, when something goes wrong at the start, when you're at the end of the project you're just a recipient of all the crap. There's not much you can do, it just goes wrong." - Developer 1

Overall, developers report the most negative experience as they feel the most project creep being at the end of the project life cycle. One developer reported experiencing "PTSD" after working on a project:

"[The work] keeps getting nominated for awards, but it is very hard to feel good about it...It is really hard to untangle the trauma from the outcome." - Developer 4

There is an even split of developers who view their role as problem-solving for the clients and those who see themselves as the coder of a website. An interesting note is that developers often see themselves as undervalued and doing the grunt work of the client project. The language in which participants describe their role is rather bleak and deflated when compared to designers.

“Just building websites that designers design and UX people conceptualise."

- Developer 1

Developers in design agencies are in a unique position as they straddle two very different communities of practice with very different priorities. DNA prides itself on its design offerings and developers are seen as a tool rather than the main priority. Although designers reported feeling lost without project context, developers' main concern is to create a functional build and deliver within budget and on-time. 
"Pfft, generally get it done. [laughter] Trying to get it done weighing budget, but yeah, most of the time it's just getting the work done. You get given a list of tasks and it's like, "Right, the priority is to get those done." Sometimes they can be influenced by what kind of client priorities there are. So we have got a project at the moment that has a bunch of tasks that have different priorities, so we're just ordering that and then working from highest down. Otherwise, yeah, it's mostly writing code."

- Developer 2

"[I belong] more [in the] developer community, but also in the developer community I'm seen as part of the design community as well as the Dev community, so it's kind of odd. I think it's because I work in the design agency. But there are certain developers in the developer community who can answer vague UX design questions better than others can."

- Developer 4

Priorities of role:

Developers reported a much more utilitarian view of their role and are the most concerned with creating a functional deliverable for the client. Due to this, developers are not as empowered or invested in the deliverable and are more focused on the quantifiable output.

"During the UX and design phase, they talked to me and asked my opinion on a search bar, I showed them a few other websites that had different solutions on how to show the bar. That saved time because I didn't have to think about it, because we used something that already exists. And for me, in terms of coding, I already had most of the code already there. We both saved time."

- Developer 1

However, there are developers that see their role as problem-solving for clients as they can offer a solution from a much more functional perspective rather than an aesthetic perspective.

"The thrill for me is the problem solving. Whether that's in the code because the role has been suited more to being quite heads down. Or whether it's right from the client and actually trying to figure out what their problem is. Or even when I'm talking to other teams 
within DNA and they have got a problem that they have come across [chuckle] that they need solving."

- Developer 3

Information received:

Developers reported experiencing the biggest breakdown in receiving project knowledge. Although there have been steps to involve developers earlier in the project process, developers often feel they have little input in the output of the client project. Issues are the most visible at the build stage of a client project as breakdowns in communication earlier on in the project are compounded. When it comes to build, the decisions and actions of the previous teams are realised, yet developers are often left responsible with little budget and time to do so.

“There's more examples of me chasing the project brief than having the brief delivered to me."

\section{- Developer 1}

"I can possibly say in general, sometimes there's a disparity between what we have promised the client and what actually then eventually used to get to the Dev Team in terms of what the best solution is. So a solution would have been designed and the UX, and the design along with that, and by the time it got to the Devs, they would say, "Oh, there's perhaps a better way of doing this." Or, "This isn't possible within the budget," that kind of thing. That's the worst kind of handover thing I can think of, but that's more of a general thing rather than a specific project thing."

- Developer 3

"The best [projects] we had are the ones where Development has had an idea of what's been going on the whole way through. So with Design, UX, we have an understanding of what needs to be built before we even get into it so we can prepare technologies that we're using and anything like that...We know how the data structure is going to work. We know how the Admin section is going to work. We know how pages are going to be linked together and things like that by being involved right from the start... As long as we have a lot of connection between, well, a conversation between Design and Dev, UX and Dev, as long as 
we stay involved there, it stays a good project because it means that we have an idea and we are not really caught off guard by anything."

\section{- Developer 2}

"The problem was, apparently the clients were really, really good throughout the entire design phase, but when it came to development we kind of had to rush it through. Like apparently budgets were cut and the rest of it, but we weren't allowed to know what the project's requirements were."

\section{- Developer 4}

"A lot of it depends on the project but some of it actually ends up being in the UX team. Quite a lot of the context is in the UX team, but that's because they've either built the feature or they got the context and business requirements from the client, but I mean, the final context is usually with the client, they're the ones who get to say whether they are happy with something... People ask different questions, something that might raise a red flag for a developer doesn't raise a red flag for a UX person."

\section{- Developer 4}

Information needed/what forms 'context' for them:

Despite being at the end of a project, developers reported the need to understand the ultimate goal of the project. Developers reported building deliverables 'blind', and not understanding the ultimate outcome. It is commonly at this stage that budget blowouts occur as

"It ended up with me not understanding what needed to be done, not being able to use the code that was to be used and reused because I did not create the original code. I did not understand it, I didn't have the support to understand it and it turned out we didn't need half of it. So we ended up about 400 hours over-budget for something that doesn't work properly. Something that we had to go back to a few months back because we forgot a key feature. We didn't understand it, I suppose."

By far, participants who identified as developers reported needing to know the most basic context - that is what the output of the project should be. 
"Where things are. Sometimes when it comes to a feature why it that way. So, for instance if you're building a navigation that's not normal navigation, sometimes you have to tell them why decisions were made, because they may seem a bit odd. And that kind of goes across different types of features. Sometimes its pointing them at resources they didn't know existed, either style guides or images somewhere else."

- $\quad$ Developer 4

"What type of project it is. If it's going to be, say, a basic revamp of the front-end or if it's going to be a complete overhaul; fundamentally what kind of project it's going to be is a good start. That determines how much more information you do need. If the client has, for example, more systems that they want to integrate in the back-end, it's good to know about those and potentially at times you go and research those. It might be things and technologies that you have never seen or used before, but generally, Devs are pretty good at puzzling those out and seeing how they fit together... They'd like a certain type of functionality like a time tabling system or something like that, for example, it's good to know at that point more about their business model because that kind of applies directly to how their customer is going to interact with their site."

- Developer 3

How information is currently received/passed on:

Developers prefer documentation, citing briefs and statement of work as important project artefacts, although one developer noted that he has "never had a written brief" during his time at DNA. However, another developer noted that documentation normally came through project managers. The incongruity about the availability of documentation shows the ineffectiveness of documentation at DNA as it is unclear whose responsibility it is to document and who to access it from.

"Either, whoever was meant to write it ran out of time -- Or they didn't think it was necessary at the time because there was-- I think when that site was originally built, there was probably only five or six of us Developers and we were all located in the same place." 
The value of documentation is the strongest in the Development team as there is an active push towards documentation as DNA grows. As code can be reused or issues in testing found, the next developer can easily understand the context of the code and changes made. Documentation is recorded in notes in the code or stored in Confluence and Jira.

"We started having more documentation put in place and this kind of stuff [ a year ago]. Documentation is really good and something we have to discipline ourselves to write... you also have to document what you've done so somebody can come back and look at it and say, "Oh you've done this." It's good."

- Developer 1

With other developers, Slack appears to be the preferred method of communication as snippets of code can be sent to be checked quickly, and files can be shared easily. It has been noted by several participants that jokes and memes often sneak into Slack channels at DNA, which can be off-putting for those outside the circle. Still, there are mixed feelings from developers about using Slack as a tool for documentation as it is a tool meant for quick messages and chat.

"I hate having briefs on Slack because everything gets lost. We don't use it the way...It's not a Trello board, you don't have a clear picture of what it is. You have threads and it keeps on going up and up and up. It's really difficult to go back. Then you have different conversations that just intersects. It just doesn't make sense at all."

- Developer 1

However, face-to-face communication remains the preferred form of communication with project managers and developers.

"Normally I walk up to them and talk to them. Often the only way, I mean, apparently email works for [project managers], but email is not really my thing though, but face-to-face works. Also, it is easier because sometime you need to show people and they need to show you, so it's much easier to do that face to face." 


\subsection{Analysis}

\section{Project Knowledge Management}

Project knowledge management at DNA is perceived to be poor overall. A lack of postproject reviews and a lack of reflection at project milestones is not industry best practice but a widely reported pain at DNA (Hanisch et al., 2009). Due to this, knowledge is retained largely with the individual who undertook the learning and it is up to the individual to transfer the knowledge to another practitioner or team. Project context is contained within one project, and even then, project knowledge is barely transferred throughout individual projects.

At first, the research findings were disappointing because there appeared to be no solution or answers to the questions or assumptions. However, upon deeper reflection, the research findings presented insights and ideas that led to the final proposed solution that resolves around assessing the individual understanding of project knowledge.

\section{Communication}

Interestingly, 'conversation' and face-to-face communication is the most common method of communicate across the three functional teams. Different functional teams have different lexicon which is more convenient to amalgamate to create shared understanding through the very time-consuming method of conversation (Bechky, 2003).

Within functional teams, practitioners have their own preferred way of communicating. From ethnographic research and primary research, the community of developers at DNA prefer to communicate on Slack with each other. Practitioners noted that developers are located in close proximity but prefer Slack to face-to-face communication.

Unsurprisingly, taking time out of a project to codify knowledge could is not an attractive solution for the visual needs of designers. Designers tend to rely on ad hoc face-to-face communication as the design process is the most iterative and collaborative. Proximity is key to communication between designers and designers at DNA often sit in close proximity with each to encourage natural conversation and collaboration (Bloomfire, 2017). 


\section{Post-project Reviews}

Overall, there is no post-project review, therefore no organisational learning. Kwan \& Balasubramanian's KnowledgeScope project implemented a post-project process evaluation stage which would add value in the form of context (2003). It is crucial that DNA implement a similar process or system in order to retain learning that could be trapped within individuals within projects.

\section{$\underline{\text { Roles }}$}

Participants are very involved in their roles and pride themselves on the quality of DNA's work. An advantage is that employees tend to be motivated and capable, however the lack of formalised processes can cause some confusion. DNA relies on employees' own initiatives to find out information and knowledge, which can be inefficient and demoralising as individuals do not feel they are empowered by the organisation. Therefore, DNA heavily relies on attracting and retaining quality talent although there is a lack of a professional development programme that successfully retains talent.

Unsurprisingly, different roles have different priority and individual participants have own lens on the role. Professional values are negotiated and although the findings about each individual and roles' priorities, what was defined as information, and how it was passed on, the higher level finding is that there seemed to be very little commonality in the way roles discussed the project, their work and their attitudes. A semantic boundary (Carlile, 2004) was discovered and led to the one of the crucial product development pivots in the project.

Developers often feel the crunch of project creep and it is concerning that some participants reported not knowing what the intended output of the client project was, especially if they were working at the end of the project process. Although respondents reported a change in the project process that includes involving developers in the earlier stages of the client project, developers still reported feeling uninvolved in the client project process.

\section{Product Development and Strategy}

The findings presented instigated a shift in the pain point from how best for DNA Design to improve knowledge sharing, to improving project knowledge management, to capturing soft 
project knowledge that gives insight into decision-making and reflective practices.

\begin{tabular}{|c|c|c|c|c|c|}
\hline \multirow[t]{2}{*}{$\begin{array}{l}\text { Key Partners } \\
\text { DNA Design: } \\
\text { - Project Managers to } \\
\text { champion and test } \\
\text { platform } \\
\text {-Developers to help } \\
\text { build an MVP } \\
\text {-Designers help } \\
\text { workshop and refine } \\
\text { MVP } \\
\text {-Senior management to } \\
\text { champion and trial } \\
\text { MVP }\end{array}$} & $\begin{array}{l}\text { Key Activities } \\
\text { - Users to capture } \\
\text { learnings and } \\
\text { context after each } \\
\text { key handover } \\
\text { - Product validation } \\
\text { through trial }\end{array}$ & \multirow{2}{*}{\multicolumn{2}{|c|}{$\begin{array}{l}\text { Value Proposition } \\
\text { - Improve efficacy } \\
\text { and efficiency in } \\
\text { siloed organisations } \\
\text { - Improve } \\
\text { communication } \\
\text { between key } \\
\text { handover points to } \\
\text { increase project } \\
\text { understanding } \\
\text { Capturing project } \\
\text { knowledge for } \\
\text { organisational } \\
\text { learning }\end{array}$}} & $\begin{array}{l}\text { Customer Relationships } \\
\text { - } \quad \text { DNA as project } \\
\text { partner established } \\
\text { - Need to access } \\
\text { wider design } \\
\text { market in } \\
\text { Wellington } \\
\text { - Need to access } \\
\text { wider market of } \\
\text { siloed } \\
\text { organisations }\end{array}$ & \multirow[t]{2}{*}{\begin{tabular}{ll}
\multicolumn{1}{l}{ Customer Segments } \\
-DNA Design: \\
$-\quad$ Project \\
& Managers \\
- & Developers \\
- & Designers \\
- & Senior \\
& management \\
-Siloed organisations \\
-Creative teams
\end{tabular}} \\
\hline & $\begin{array}{l}\text { Key Resources } \\
\text { - } \quad \text { DNA developers to } \\
\text { build MVP } \\
\text { - } \quad \text { Designers help } \\
\text { workshop and } \\
\text { refine MVP } \\
\text { - Senior management } \\
\text { to champion and } \\
\text { trial MVP }\end{array}$ & & & $\begin{array}{l}\text { Channels } \\
\text { - } \quad \text { Targeted digital } \\
\text { marketing strategy } \\
\text { to reach wider } \\
\text { markets of creative } \\
\text { teams and siloed } \\
\text { organisation - } \\
\text { Linkedln, Facebook } \\
\text { communities? } \\
\text { Networking } \\
\text { through startup } \\
\text { events and design } \\
\text { networking events }\end{array}$ & \\
\hline \multicolumn{3}{|c|}{$\begin{array}{l}\text { Cost Structure } \\
\text { - Cost of MVP development and services } \\
\text { - } \quad \text { Cost of ongoing development until product enters the } \\
\text { market } \\
\text { - Cost of running server space when product enters the } \\
\text { market }\end{array}$} & \multicolumn{2}{|c|}{$\begin{array}{l}\text { Revenue Streams } \\
\text { - } \quad \text { Freemium? } \\
\text { - Software as a Service? } \\
\text { - } \quad \text { Subscription? }\end{array}$} & \\
\hline
\end{tabular}

Figure 1. Initial business model canvas

The original preliminary business model canvas (Osterwalder \& Pigneur, Business Model

Generation, 2010) was based on the value proposition assumed by the initial research assumptions and area of 'exploring knowledge sharing in siloed organisations' (refer to

Figure 1 above). The business model canvas. The proposed business model canvas did not evolve much as the project pivoted to 'improving knowledge sharing at DNA.' 


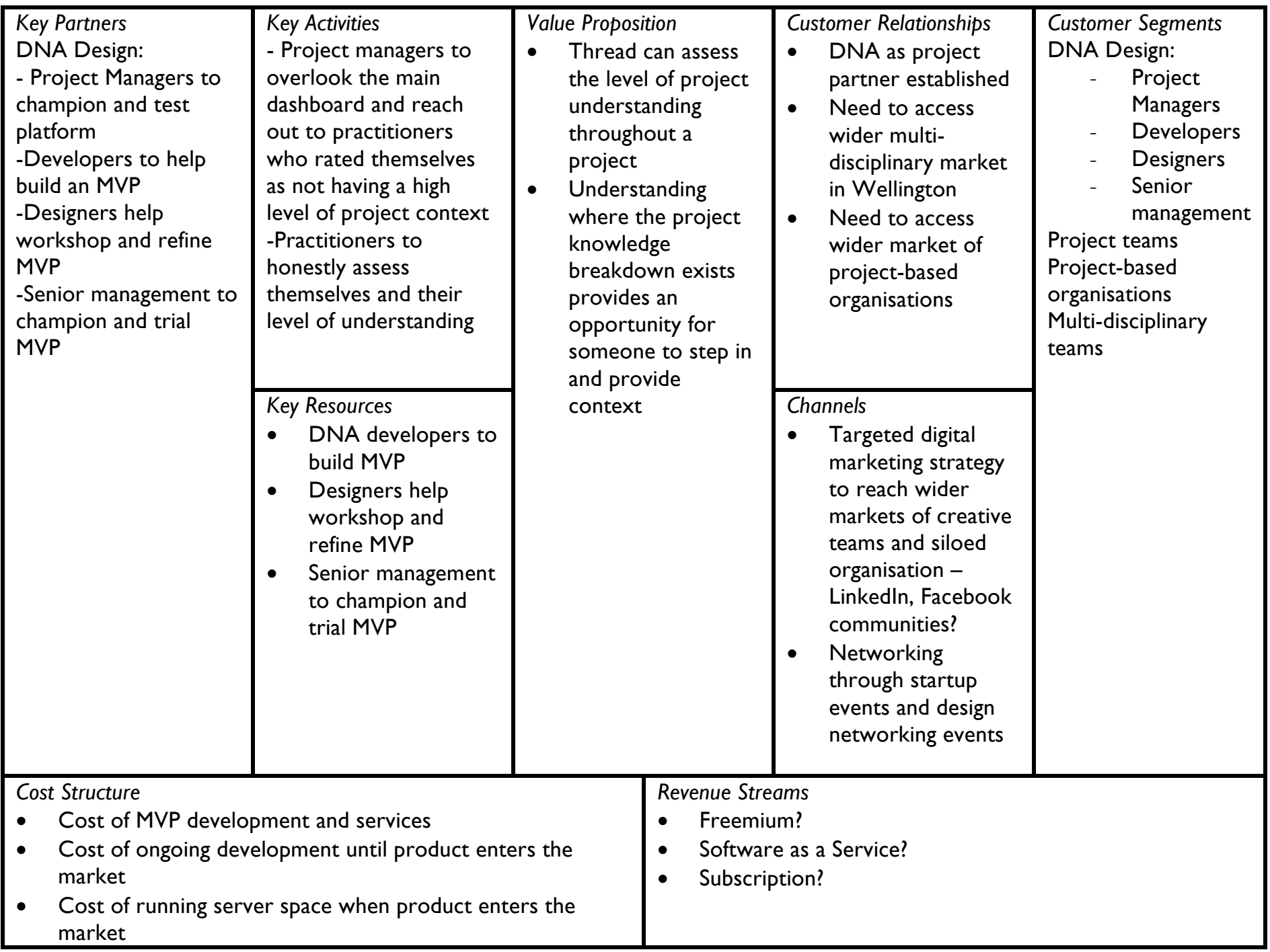

Figure 2. Revised business model canvas

Initially the project focused on knowledge sharing in siloed organisations but the findings demonstrated the importance of boundary spanning and the shared understanding of the decision-making process. The goal is to not to capture 'context', but to measure the level of shared understanding and allowing for hazards to be identified. Only the value proposition, key activities, customer relationships and customer segments of the business model canvas were changed as a result of the final pivot to the research project of 'managing context in project environments'. 


\section{Pivots in the Product Development Strategy}

From the findings, three main pivots in the product development took place:

While the assumptions about knowledge sharing at DNA were proven to be correct, developing and introducing a new knowledge repository felt redundant as the technology was already readily available and adopted at DNA.

The first pivot in product development was to focus on developing a knowledge management strategy in which the proposed 'solution' would be a framework or guidelines that captured relevant project information. It was hoped that what was defined as 'context' could be triangulated from the primary research through common project requirements and themes. A component of the knowledge management strategy was formalised post-project reviews to retain organisational learning about project processes from both financially successful and unsuccessful projects.

It was hoped that research could identify and refine shared vocabulary used across the project life cycle in order to define project context through a common lexicon according to Carlile's syntactic approach to boundary management (2004). There was an attempt to develop the 5 Ws - who, what, where, why, when - into a framework that could be protected by IP and then commercialised. However, developing a common lexicon to capture project context was more difficult than anticipated as participants within the same function group required different levels and different kinds of project information (Bechky, 2003). Furthermore, commercialising a framework or guideline proved to be difficult as the business model proved to be unsustainable and a functional platform needed to be developed.

Thread uses proactive prompting to track understanding of project 'context' - the soft knowledge discussed in project meetings by:

- Tracking what team members are on the project for proactive practitioners to know who to turn to ask for information or project context;

- Capturing organisational learning for DNA in order to scope next project, generate leads, capture client relationship details, provide insights for financially successful and unsuccessful projects; 
- Generating future value by using predictive analytics to flag lagging indicators in a client project so project managers and practitioners can step in to address project knowledge gaps.

From the findings, the project shifted from developing a knowledge repository into looking at how best to capture context to the final proposed solution of a project health indicator that tracks the attitudes of project team members in order to gage shared understanding along the project life cycle. Instead of developing a new way to codify knowledge, the proposed product should aim to track that individuals in a project team have the optimal level of understanding throughout the project lifecycle.

\section{Assumptions about Product Development}

At the beginning of the project, it was assumed that a knowledge repository or project management platform would be the best fit to improve the issues of efficiency and efficacy. At analysing the competitive environment, it became clear that the project management and knowledge management markets were saturated, although the issue of understanding context within a project and in project environments still exists.

The high-level finding is that there exists a need for a tool that evaluates the level of shared understanding within a project environment. Instead of investigating a market opportunity for another project management or knowledge repository tool, assumptions about the product development strategy shifted towards creating a tool that can prompt conversations to enable better assessment of project knowledge management.

\section{Assumptions about Market Opportunity}

The initial assumptions about the market opportunity acknowledges that the markets for project management tools and knowledge repositories are already heavily saturated. From the findings, it was clear that there exists a need for a project knowledge management monitoring software that would be used alongside current knowledge management platforms.

Instead of continuing to explore options to capture 'context' and soft product knowledge, a 'Blue Ocean Strategy' was consciously adopted to investigate potential uncontested market space (Kim \& Mauborgne, 2004). It is assumed that there currently exists no other software that aims to track project team members' understanding of a project. 


\section{Discussion}

Chapter introduction:

The major findings leading to the final proposed solution of Thread are discussed in this chapter.

\subsection{Major Findings}

Participants reported using different methods to keep track of project tasks, team tasks and knowledge indicating a concerning knowledge misalignment (Reich et al., 2011). When practitioners interacting across functional teams, there is a lot of guessing into what project information needs to be passed on from one practitioner to another if a standardised handover process is absent.

The most crucial elements of information that forms context, for the whole team, are budget, scheduling, knowing what is expected of the project from both the client and the internal team, and what the expected output is. The shared understanding across a project is low due to information being siloed within individuals as there is a lack of formal standardised handover processes for the thread of knowledge to flow from the beginning of the project to delivery.

In project environments, the expectations and outcomes are fluid and ever-changing. However, there should be some measure to track the clarity of understanding across team members and efforts to ensure that every individuals' expectations and understanding are aligned at consistent points throughout a project.

Essentially, project managers should aim to act as boundary spanners and enable the flow of project knowledge from the beginning to delivery. Project managers have the most contact points with a range of practitioners and clients within projects and they are able to provide the most clarity around internal and external expectations.

Project environments are chaotic to operate in as context is ever-changing (Snowden \& Boone, 2007). To complicate the situation, information passed on from one practitioner to another is filtered with the views and roles of individuals. 
Different roles require different lexicon. A standardised project lexicon to help carry shared understanding through a project, focusing on soft project knowledge, could be implemented in order to solidify the universal project priorities (Bechky, 2003; Carlile, 2004).

Fundamental to capturing context at DNA is the development of effective and universal prompt questions that are unintrusive, valuable for each practitioner, and valuable from a business perspective for the organisation. Furthermore, participants have a 'us vs them' mentality from the vocabulary used in primary research data, using language to unknowingly create a semantic siloed culture ("When working with creative people..").

Hanisch et al. found that the goals of project knowledge management were to avoid duplication of work, achieve learning by repetition, promoting innovation, standardising best practice, and achieve the efficient allocation of resources (p. 152, 2009). Participants in the research mirrored the same problems, leading to the conclusion there is no effective knowledge management strategy at DNA currently.

\section{Implications for Project}

From the findings, the project moved from developing a knowledge repository as it became clear that participants were already using a plethora of software platforms and workarounds to address the issues faced by practitioners.

\section{Reflection on Initial Assumptions}

It was initially assumed that a communication breakdown exists somewhere in the project lifecycle and that a potential knowledge management strategy or platform could encourage communication. However, the greatest learning is that most participants reported not having enough project context to effectively do their job, and that workarounds are frequently used.

\section{Theoretical Implications}

The literature suggests that knowledge sharing is an either/or activity of socialisation or codification but the research shows that changing organisational dynamics and structures complicates the matter. There is no research into the assessment of the effectiveness of knowledge management strategies and an opportunity exists for future empirical research. 


\section{Business Case}

\section{Project Background}

DNA Design is a leading user experience agency with a geographically dispersed team in New Zealand and creates amazing, effective user experiences for their clients ( (DNA Designed Communications Limited, 2018). Unfortunately, the user experience of the internal team members does not reflect that.

\section{Problem}

DNA, like many project-based organisations, relies on having excellent specialists in multidisciplinary teams to create high quality work. The downsides to having a highly knowledgeable diverse team are that different roles and individuals have their own personal ways of working, preferences for communication, and may not share While practitioners on client projects at DNA are empowered by and passionate about the work they do, there is room for improvement in project knowledge management.

Hard files and codified knowledge is only useful to those that understand it, those in the same disciplinary field. Developers are more likely to search for notes in code and Jira, designers seek more face-to-face communication, and project managers chase after timesheets.

What is universal in the understanding of a project is "context" - the soft knowledge that is often passed from individual to individual via ad hoc means. Due to an inadequate handover process, it is up to individuals to ask questions for project context and the onus is on individual practitioners to follow the thread of knowledge from the client through to delivery.

\section{Key findings}

- Handovers at DNA represent a complex, semantic boundary (Carlile, 2004);

- There is a lack of shared understanding of knowledge in projects;

- There is a misalignment between practitioners' priorities on a client project;

- The benefits of knowledge management has been well-researched yet not fully realised at DNA. 


\section{Recommendations}

Current project management solutions focus on the 'know-what' and 'know-how' of project knowledge, while Thread aims to conquer the 'know-why' of a project's trajectory (Lundvall \& Johnson, 1994). Thread uses practitioners' self-assessment to evaluate the ad hoc handover processes in order to gauge individuals who might not be receiving project knowledge and may need more clarification.

There is a lack of formal handover processes at DNA due to budget, resourcing and time constraints, common issues in project environments. It is recommended for handover processes to be formalised or led by a project manager, ensuring that every project team member is 'on the same page' and for the project manager to check-in on individuals proactively. Time for handover processes and meetings should be allocated for outside of project time.

On an individual level, knowledge management enhances job satisfaction, commitment to the organisation, and performance (Kianto, Vanhala, \& Heilmann, 2016). However, DNA is not currently realising the benefits of knowledge management as there is an absence of formal knowledge management and sharing strategies and processes. It is recommended for DNA to adopt a simple knowledge sharing strategy enabled by Thread.

\section{Project Goals and Vision}

Despite a range of software platforms, a technologically-adept team, and a relatively open organisational culture, project context is not distributed evenly through the client project life cycle. The project goals include understanding current challenges faced by DNA that hinder the flow of project knowledge, whether it be project boundaries, gatekeepers of information, or in DNA's case, a mixture of both.

Thread's vision is to track the understanding of project team members across a project lifecycle in real time, allowing for immediate clarification of expectations. Thread aims to focus on the qualitative measures of project knowledge understanding. Measures of project health and success are traditionally quantitative (Freeman \& Beale, 1992), however, measures of employee productivity are often linked with qualitative measures such as job satisfaction and work self-efficacy (Edwards, 2015). 


\section{Business Model Design}

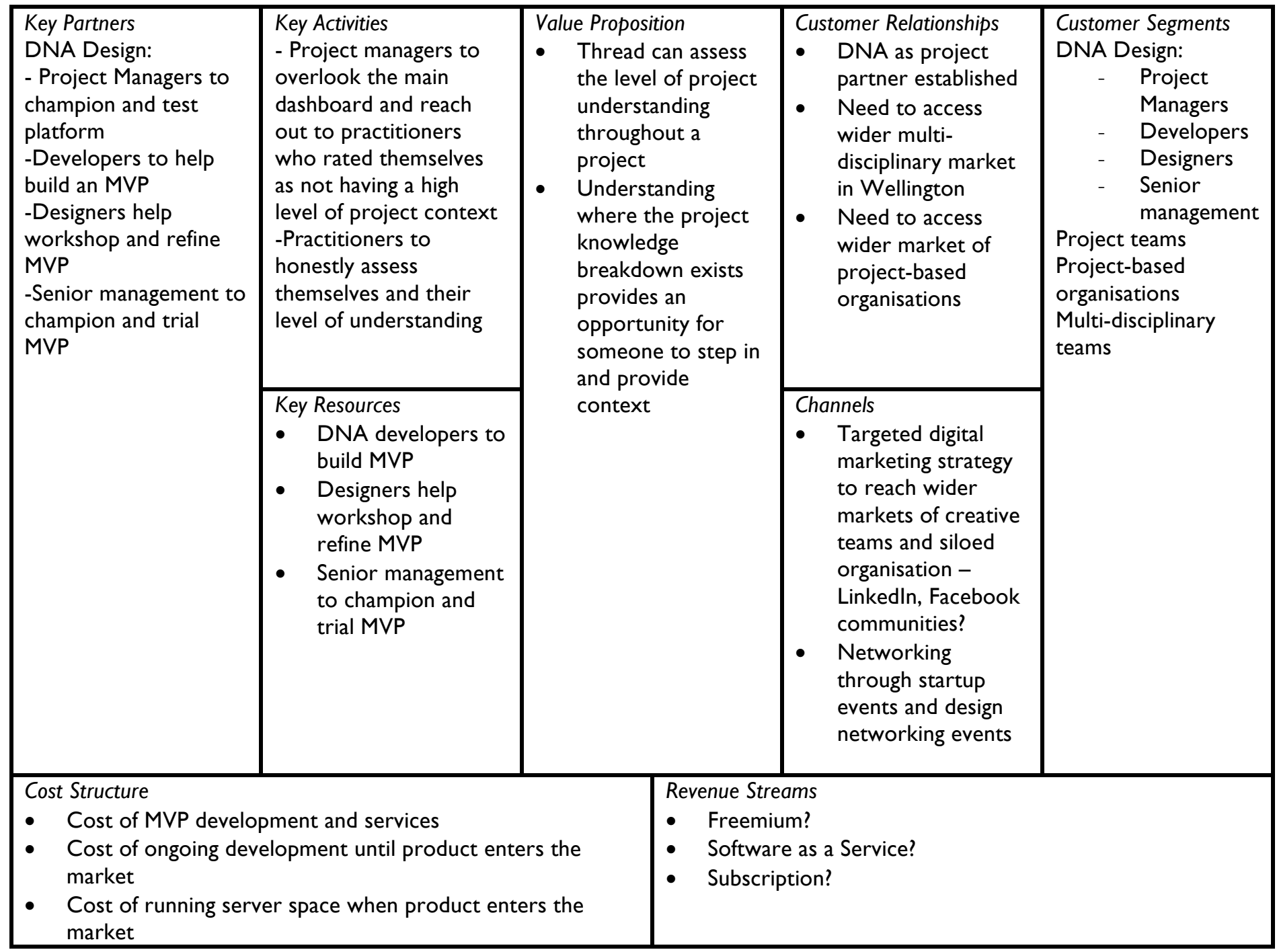

The business model design needs to be further investigated as Thread is still in a very early start-up phase and the time spent in discovery and ideation took time away from investigation of revenue streams. However, it is envisioned that Thread will follow a technologicallyfocused revenue stream with a competitive pricing strategy. 


\section{Assumptions}

The main assumptions of this project are:

1. Developing and implementing a project understanding indicator can help project management strategies to improve communication, increase work self-efficacy, and improve productivity in project-based organisations (using DNA as a case study).

2. The proposed platform offers opportunities for commercialisation and can enter a niche market.

Underlying assumptions include:

- A knowledge sharing breakdown does exist within DNA and other project-based environments.

- DNA's functional teams operate well within their boundaries and established organisational structures and processes inadvertently perpetuate those boundaries.

- Tools and processes currently in place can encourage these confines. Different functional teams prefer different technological platforms which can hinder the transfer of knowledge and there is no consensus on one best platform across teams.

- Not all knowledge is shared equally between team members and shared knowledge is framed within the priorities and values of a role. That is, a project manager is likely to pass down knowledge that is deemed important to their role (ie. budgets and deadlines). This framing skews data and information transferred along the knowledge chain, which can create misunderstandings in communication and misaligned priorities.

- Knowledge management and communication breakdowns are not unique to DNA and there is no current best practice for the creative sector. 


\section{Market Validation and Development}

The issue of capturing project knowledge is not unique to DNA Design. While DNA is the project partner, a wider market of creative multi-disciplinary teams should be evaluated.

Project management software and platforms currently on the market focus on tasks, breaking projects down into bite-sized digestible to-do lists (see Float, Trello, Asana). Thread aims to give practitioners in any project team an understanding of why they're doing the task, improving team dynamic, self-efficacy and allowing them the chance to suggest a better way of doing.

Project management systems is a saturated market. Thread aims to meet the needs of information-rich project-organisations where knowledge is actively created collaboratively and iterated rather than projects that follow a linear process. Projects that do not necessarily follow a checklist so a checklist-approach cannot be used to pass on information.

What is clear from data collected through primary research is that face-to-face communication is still the preferred way of sharing knowledge at DNA. Therefore, there is no need to enter the market with yet another project management, knowledge repository, or messenger tool. When practitioners have issues, it is the easiest to get clarity by ad hoc conversation or email and usually they seek out who they perceive to know the information, usually the project manager for clarity on expectations. 


\section{Current Solutions}

Thread does not aim to replace current solutions on the market but can be used alongside current solutions. While DNA, and many other project organisations, use knowledge repositories and expect practitioners to retrieve knowledge themselves.

That is not currently the case in a complex multi-disciplinary. Where Thread adds value is through the function for users to self-assess and report their level of understanding in a project in order for corrective measures to be taken in real-time, before the client project starts to lag.

The primary research found a list of software platforms currently used by staff at DNA to manage projects, communicate and collaborate within and across teams, store and share knowledge. These current solutions can be broken down into three groups: project management, collaboration and communication, and documentation.

- Project Management platforms:

Float, Trello, Google Spreadsheets

- Communication \& Collaboration:

Slack, InVision, Zoom, Skype

- Documentation:

Google Docs, Jira, Confluence 


\section{Features of Thread}

Thread is a project-centric tool to evaluate the alignment of project knowledge in real time. At this still exploratory stage, a MVP has been developed that allows for individuals within a project team to evaluate their attitudes about project knowledge and understanding.

While traditional measures of project success of are largely quantitative (Freeman \& Beale, 1992), qualitative factors such as schedule, quality of work and stakeholder satisfaction are being considered (Westfield, 2015). Thread puts the organisation's team members into focus as it assesses the attitudes about the value of the meeting, attitudes about worker self-efficacy, attitudes about the quality of the project's output, attitudes about the delivery of the project, and attitudes about budget constraints.

Thread works alongside a scheduling tool, such as Microsoft Outlook. When a scheduled meeting has ended, a push-notification will remind users to anonymously rate their attitudes about the meeting that has just passed, their level of understanding about their tasks, and their confidence about the project (budget, time, quality).

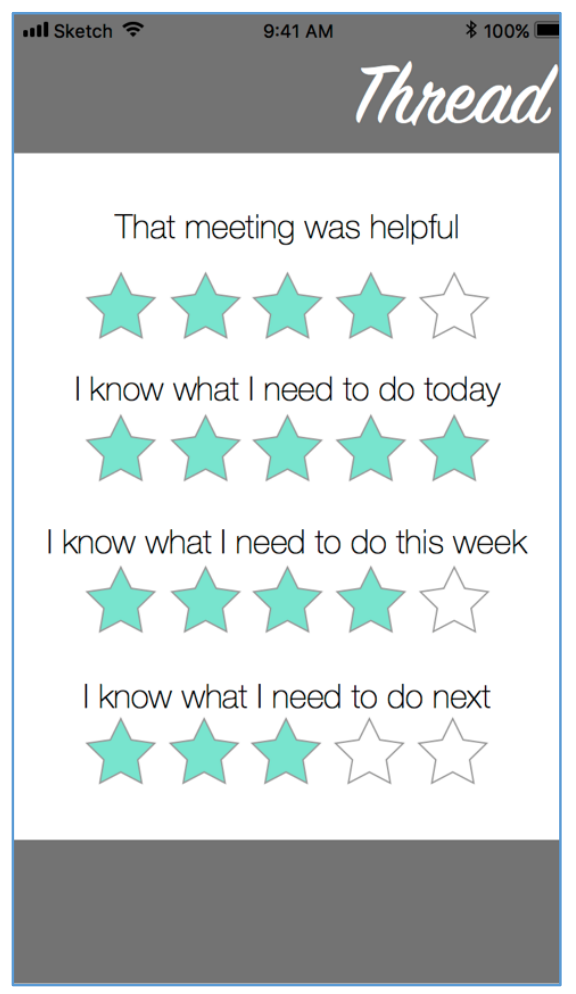

The data aggregated will give the project manager a bird's-eye view of the individual's understanding, and feedback for the project manager to improve future meetings for clarity if needed. If a project team member rates themselves low on understanding the tasks for the project, it gives the project manager a chance to meet with the individual and either clarify expectations themselves, find the relevant information, or put the 'atrisk' practitioner in touch with a relevant team member.

For the project team member, Thread can act as a flagging system so project managers know who to prioritise and how best to allocate their own time to manage and reset the expectations of the project team member. If a practitioner is very lost, the project manager can then dedicate more time to clarifying their expectations. 


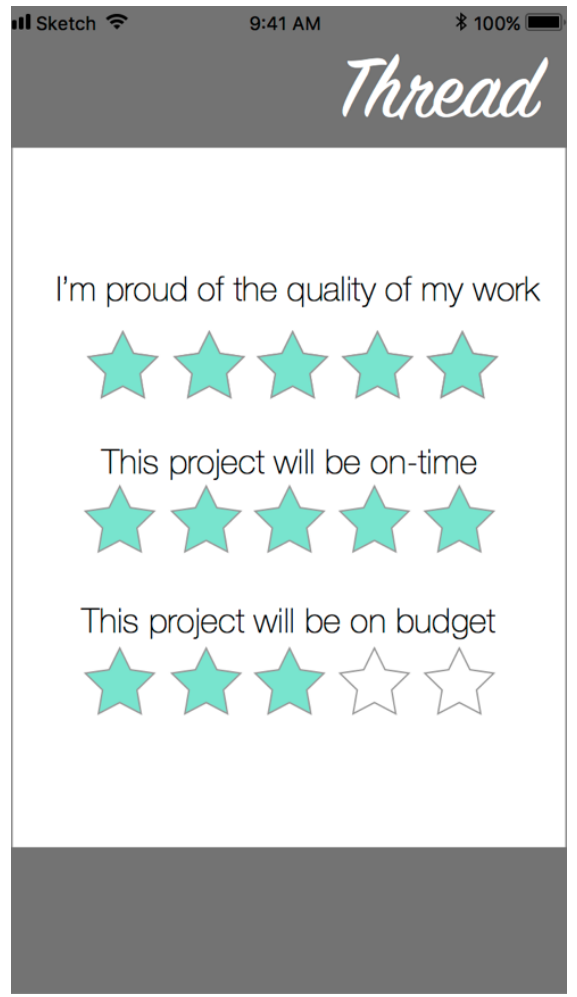

The three universal priorities for project team members are quality of work, budget and time. These factors can also indicate the level of work self-efficacy and stress a project team member might be experiencing.

The set of three rankings help project managers gauge how perception of how the project is tracking in terms of deliverables. A project that is rated negatively by team members on these three dimensions could signal an unexpected increase in the complexity of the project.

The project manager can access the aggregated data from a dashboard (not pictured) that is plotted on a time and budget axis. Members on a project are plotted and project managers are able to see individuals that are lagging. As it is an anonymised process to all expect the project manager, it is hoped that project team members are able to be honest in their assessment.

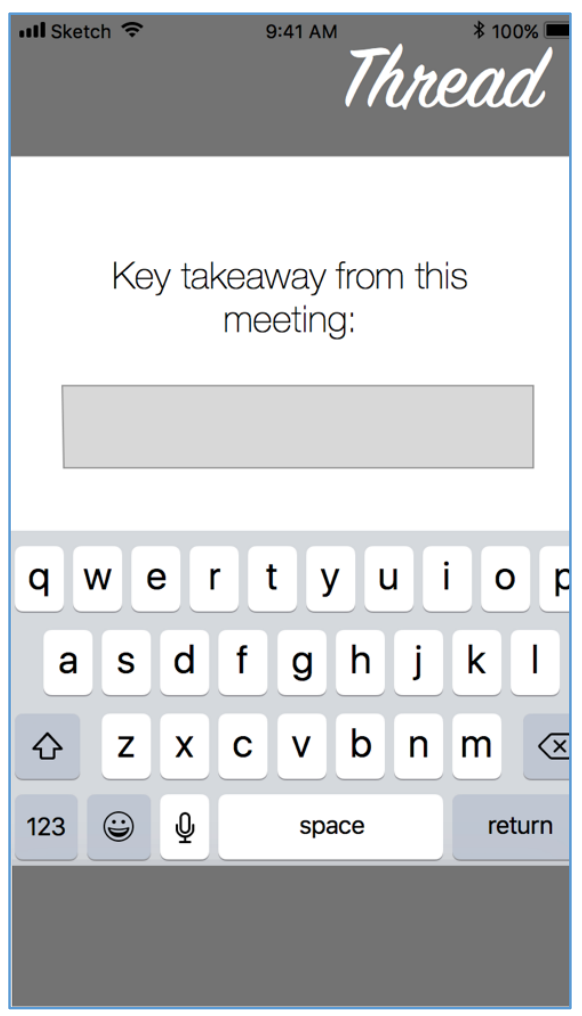




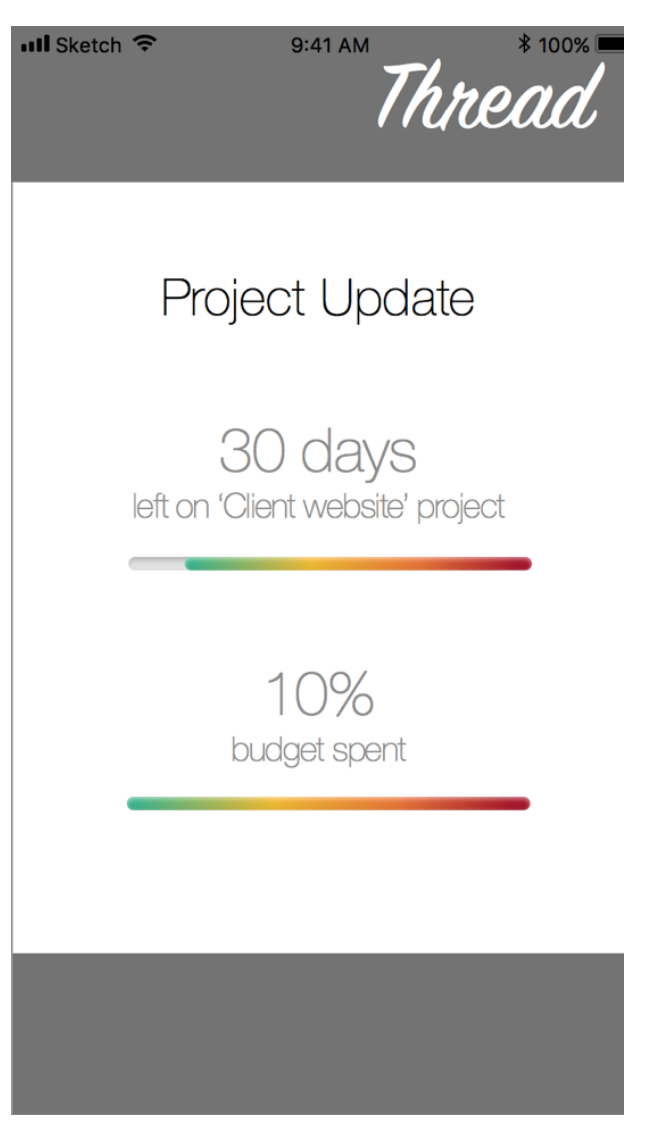

Project team members are incentivised to rate and update their attitudes about the health of the project as the last screen displays the countdown to the deadline and budget spent. This allows for greater autonomy so project team members can collaborate and decide on what is within scope under the current conditions.

If a project is tracking well in terms of a long deadline and a huge budget, the project team might decide to add more complex features in order to produce high quality work and present innovative, complex solutions.

It is hoped that Thread can enable DNA to implement a post-project review with a credible analysis of qualitative data as there is a record of where in the project practitioners found difficult or very unclear, therefore providing an opportunity for learning and improvement.

\section{Future Developments}

It is hoped that Thread can add value by collecting enough data to generate predictive analysis in order to flag when future client projects are lagging or when there is a critical knowledge breakdown that could lead to project creep. It is also hoped that predictive analytics can prevent scope creep and cost creep by offering DNA historical data of past client projects and help scope similar future projects. 


\section{Resource Requirements and Returns}

\section{Skills Required}

The success of Thread relies on the technical knowledge of how to design, code and build the software as a website dashboard (for the project managers to overlook) and a mobile app (for both project managers and practitioners. As a startup with a lone founder, options to obtain the skills required are slim. The only option would be to find a co-founder or co-founders with the technical skills needed to refine the MVP. The skills needed would be UX/UI design, wireframing, and development.

\section{Funding}

As Thread is at a very early startup stage, it is most beneficial to first further develop and validate the MVP by participating in local incubator programmes before raising funds. Possible sources of funding and assistance could be Victoria University of Wellington's commercialization arm, Viclink, and the Victoria Entrepreneur Bootcamp (Viclink, 2015). 
Proposed Timeline for Activities

\begin{tabular}{|l|l|l|l|l|l|l|l|l|l|l|l|l|}
\hline & May & June & July & Aug & Sep & Oct & Nov & Dec & Jan & Feb & Mar & April \\
\hline $\begin{array}{l}\text { Present and propose } \\
\text { recommendations to DNA }\end{array}$ & & & & & & & & & & & & \\
\hline Validate MVP with DNA & & & & & & & & & & & & \\
\hline Refine MVP & & & & & & & & & & & & \\
\hline Finalise product & & & & & & & & & & & & \\
\hline $\begin{array}{l}\text { Explore other target } \\
\text { markets }\end{array}$ & & & & & & & & & & & & \\
\hline Validate other markets & & & & & & & & & & & & \\
\hline Validate channels to market & & & & & & & & & & & & \\
\hline Explore ways to protect IP & & & & & & & & & & & & \\
\hline Secure investor funding & & & & & & & & & & & & \\
\hline Take to market & & & & & & & & & & & & \\
\hline
\end{tabular}

A proposed timeline for activities in the next 12 months is centered around being involved in the Victoria Entrepreneur Bootcamp (November - February). It is crucial for Thread to be validated and tested with DNA to validate the assumptions about its value proposition and refine Thread's features. The proposed timeline is highly ambitious as it assumes that Thread does add value in the way it proposes and no more pivots will take place. 


\section{Conclusion}

This research project has demonstrated a critical need for a project knowledge assessment tool and strategy to be developed. While knowledge management literature, theories and strategies are currently focused on the best way of codifying or socializing knowledge in project teams and organisations, there exists no measure of analysis on the real impact of these solutions on project teams.

The concept of Thread came into ideation from in-depth qualitative research at DNA Design, a perfect opportunity to examine and explore issues about the knowledge misalignment between functional teams in a real-world setting. Although the initial project focused on capturing knowledge from project team members to create a knowledge repository for organizational learning, the project pivoted to the idea of a leading project health indicator based on attitudes about project knowledge and understanding.

The key findings from open-ended, semi-structure one-on-one interviews found that all participants had experienced negative projects where it was not clear what was expected of them. The sources of the confusion were both internal and external - some participants reported being at the end of a project life cycle hindered the flow of knowledge and some participants reported that client expectations were not communicated or clarified.

There was no thread of knowledge to follow.

The limitations of this report is time constraint. Due to the complexity of the project, a large amount of time was left to uncovering the priorities of practitioners and in the ideation of the MVP. The next step in the project would be to develop and refine the business case, especially in the stage of market validation by working with the project partner 


\section{References}

Bartsch, V., Ebers, M., \& Maurer, I. (2013). Learning in project-based organizations: The role of project teams' social capital for overcoming barriers to learning . International Journal of Project Management, 239-251.

Bechky, B. A. (2003). Sharing Meaning Across Occupational Communities: The Transformation of Understanding on a Production Floor. Organization Science, 312 - 330.

Bloomfire. (2017). 5 Ways To Increase Knowledge Sharing In Your Organization. Retrieved from Bloomfire: https://bloomfire.com/blog/522359-5-ways-to-encourage-knowledge-sharingwithin-your-organization/

Caldwell, T. (2017, February 9). 5 reasons to add Confluence if you're a Jira Software team. Retrieved from Atlassian Blog: https://www.atlassian.com/blog/confluence/5-reasons-to-addconfluence-if-you-are-a-jira-software-team

Carlile, P. R. (2004). Transferring, Translating, and Transforming: An Integrative Framework for Managing Knowledge Across Boundaries. Organization Science, 15(5), 555-568.

Cooper, R. G. (2017). Idea-to-Launch Gating Systems: Better, Faster, and More Agile. ResearchTechnology Management , 60(1), 48-52.

DNA Designed Communications Limited. (2018). Awards / DNA. Retrieved from Designing Customer Experience: https://dna.co.nz/our-work/awards/

DNA Designed Communications Limited. (2018). People / DNA. Retrieved from Designing Customer Experience: https://dna.co.nz/who-we-are/people/

Edwards, S. (2015, October 29). Examining the Relationship Between Workplace Satisfaction and Productivity. Retrieved from Inc.: https://www.inc.com/samuel-edwards/examining-therelationship-between-workplace-satisfaction-and-productivity.html

Freeman, M., \& Beale, P. (1992, March). Measuring project success. Project Management Journal, $23(1), 8-17$.

Gasik, S. (2011). A Model of Project Knowledge Management. Project Management Journal, 42(3), 23-44.

Griffin, T. (2017, February 18). 12 Things about Product-Market Fit. Retrieved from Andreessen Horowitz: https://a16z.com/2017/02/18/12-things-about-product-market-fit/

Hager, S. (2016, January 14). 7 WAYS TO BRIDGE THE GAP BETWEEN DESIGN AND DEVELOPMENT. Retrieved from Scalable Path: https://www.scalablepath.com/blog/7-waysto-bridge-the-gap-between-design-and-development/

Hanisch, B., Lindner, F., Mueller, A., \& Wald, A. (2009). Knowledge management in project environments. Journal of Knowledge Management, 13(4), 148-160.

Hansen, M. T., Nohria, N., \& Tierney, T. (1999, March-April). What's Your Strategy for Managing Knowledge? Harvard Business Review, pp. 106-116.

Kianto, A., Vanhala, M., \& Heilmann, P. (2016). The impact of knowledge management on job satisfaction. Journal of Knowledge Management, 20(4), 621-636. 
Kim, W. C., \& Mauborgne, R. (2004, October). Blue Ocean Strategy. Harvard Business Review, pp. 71-80.

Kwan, M. M., \& Balasubramanian, P. (2003). KnowledgeScope: managing knowledge in context. Decision Support Systems, 35, 467-486.

Lawson, B. (2005). How Designers Think : Demystifying the Design Process (4th Edition ed.). Architectural Press.

Massingham, P. (2014). "An evaluation of knowledge management tools: Part 2 - managing knowledge flows and enablers. Journal of Knowledge Management, 18(6), 1101-1126.

Maurya, A. (2012, February 28). Why Lean Canvas vs Business Model Canvas? Retrieved from Love the Problem: https://blog.leanstack.com/why-lean-canvas-vs-business-model-canvasaf62c0f $250 f 0$

Mueller, J. (2012). Knowledge sharing between project teams and its cultural antecedent. Journal of Knowledge Management, 16(3), 435-447.

Mueller, J. (2012). Knowledge sharing between project teams and its cultural antecedents. Journal of Knowledge Management, 16(3), 435-447.

Mueller, J. (2015). Formal and Informal Practices of Knowledge Sharing Between Project Teams and Enacted Cultural Characteristics. Project Management Journal, 46(1), 53-68.

Osterwalder, A., \& Pigneur, Y. (2010). Business Model Generation. Hoboken, New Jersey: John Wiley \& Sons.

Osterwalder, A., Pigneur, Y., Bernarda, G., \& Smith, A. (2014). Value Proposition Design. Hoboken, New Jersey: John Wiley \& Sons.

Reich, B. H., Gemino, A., \& Sauer, C. (2014, May). How knowledge management impacts performance in projects: An empirical study. International Journal of Project Management, 32(4), 590-602.

Reich, B. H., Gemino, A., \& Sauer, C. (2014). How knowledge management impacts performance in projects: An empirical study . International Journal of Project Management, 32(4), 590-602.

Salesflare. (2018). How Slack became a leading communication platform. Retrieved from Salesflare Blog: https://blog.salesflare.com/how-slack-became-a-leading-communication-platform$17 \mathrm{~b} 4182 \mathrm{df} 425$

Swan, J., Scarbrough, H., \& Newell, S. (2010). Why don't (or do) organizations learn from projects? Management Learning, 41(3), 325-344.

Turner, B. A. (1994). The Symbolic Understanding of Organizations. In M. Reed, \& M. Hughes (Eds.), Rethinking Organization: New Directions in Organization Theory and Analysis (pp. 46-66). London: SAGE Publications.

Viclink. (2015). What Can Bootcamp Do For Me? Retrieved from Victoria Entrepreneur Bootcamp: http://www.vicbootcamp.co.nz/

Westfield, J. (2015, September 28). 5 Ways To Measure Project Success. Retrieved from Project Manager: https://www.projectmanager.com/blog/5-ways-to-measure-project-success 


\section{Appendices}

Appendix A: Information for participants

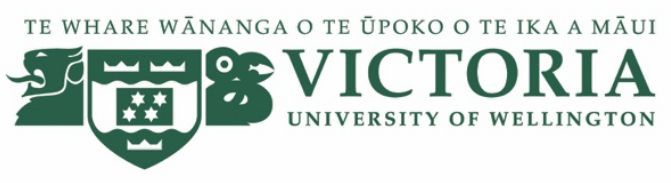

\section{Exploring Knowledge Sharing in Siloed Organisations}

\section{INFORMATION SHEET FOR PARTICIPANTS}

Thank you for your interest in this project. Please read this information before deciding whether or not to take part. If you decide to participate, thank you. If you decide not to take part, thank you for considering my request.

\section{Who am I?}

My name is Flora Lu and I am a Masters student in Innovation and Commercialisation at Victoria University of Wellington. This research project is work towards my thesis.

\section{What is the aim of the project?}

This project aims to explore how DNA Design learns as an organisation and how knowledge is shared between team members. This research has been approved by the Victoria University of Wellington Human Ethics Committee 0000024507.

\section{How can you help?}

You have been shortlisted by Grenville as someone who has great insight and understanding into the inner workings of DNA. I would really appreciate hearing your views to inform my research into ways DNA can be improved.

If you agree to take part I will interview you at the DNA office. I will ask you questions about your role and values. The interview will take 30 minutes. I will record the interview 
and write it up later. You can stop the interview at any time, without giving a reason. You can withdraw from the study by contacting me at any point before $31^{\text {st }} \mathrm{June} 2017$. If you withdraw, the information you provided will be destroyed or returned to you.

\section{What will happen to the information you give?}

You will not be named in the final report but your organisation will be named.

Only my supervisors and I will read the notes or transcript of the interview. The interview transcripts, summaries and any recordings will be kept securely and destroyed 1 year after the research ends.

\section{What will the project produce?}

The information from my research will be used in my Masters thesis.

\section{If you accept this invitation, what are your rights as a research participant?}

You do not have to accept this invitation if you don't want to. If you do decide to participate, you have the right to:

- $\quad$ choose not to answer any question;

- $\quad$ ask for the recorder to be turned off at any time during the interview;

- $\quad$ withdraw from the study before $31^{\text {st }}$ October 2017 ;

- $\quad$ ask any questions about the study at any time;

- $\quad$ receive a copy of your interview recording (if it is recorded);

- $\quad$ read over and comment on a written summary of your interview;

- be able to read any reports of this research by emailing the researcher to request a copy.

\section{If you have any questions or problems, who can you contact?}

If you have any questions, either now or in the future, please feel free to contact either:

\section{Student:}

Name: Flora Lu

University email address: luflor@vuw.ac.nz

\section{Supervisor:}

Name: Dr Jocelyn Cranefield

Role: Supervisor

School: Information Management 
jocelyn.cranefield@vuw.ac.nz

\section{Human Ethics Committee information}

If you have any concerns about the ethical conduct of the research you may contact the Victoria University HEC Convener: Associate Professor Susan Corbett. Email susan.corbett@vuw.ac.nz or telephone+64-4-463 5480. 
Appendix B: Participant consent form

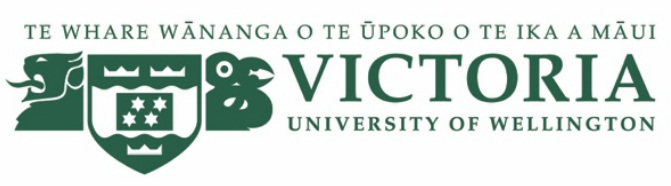

\section{Exploring Knowledge Sharing in Siloed Organisations}

\section{CONSENT TO INTERVIEW}

This consent form will be held for 1 year.

Researcher: Flora Lu, Victoria University of Wellington.

- I have read the Information Sheet and the project has been explained to me. My questions have been answered to my satisfaction. I understand that I can ask further questions at any time.

- I agree to take part in an audio recorded interview.

I understand that:

- I may withdraw from this study at any point before $31^{\text {st }}$ October 2017, without giving any reason, and any information that I have provided will be returned to me or destroyed.

- The information I have provided will be destroyed 1 year after the research is finished.

- Any information I provide will be kept confidential to the researcher and the supervisor. I understand that the results will be used for a Masters report and a summary of the results may be used in academic reports and/or presented at conferences.

- My name will not be used in reports, nor will any information that would identify me. 
- $\quad$ I would like a summary of my interview:

Yes No

- I would like a copy of my recorded interview:

Yes No

- I would like to receive a copy of the final report and have added my email Yes

No address below.

Signature of participant:

Name of participant:

Date:

Contact details: 
Appendix C: Final interview guide

Tell me about your role at DNA.

At what stage of the client project do you typically work on?

What are your priorities on projects?

What do you see as a successful handover?

Can you tell me about a good handover process you've been a part of?

What made it a good experience - why?

What stage of the project was this at?

What tools were used?

Who do you receive info from/pass info on to?

What impact did this good handover process have on you personally?

Can you tell me about a bad handover process you've experienced?

What made it a bad experience - why?

What stage of the project was this at?

What tools were used?

Who did you receive info from/pass info on to?

What impact did this bad handover process have on you personally?

What do you need in a handover (to do your job well) - why?

What tools?

What processes?

What info? 